\title{
LA POTESTAD REGLAMENTARIA DE LAS ENTIDADES TERRITORIALES. LOS REGLAMENTOS REGIONALES, LAS ORDENANZAS Y LOS REGLAMENTOS MUNICIPALES
}

\author{
Eduardo Cordero Quinzacara (iD) \\ Profesor de Derecho Administrativo \\ Universidad Católica del Norte \\ Sede Antofagasta \\ Universidad de Antofagasta
}

SUMARIO: 1. Aspectos generales. 2. La Potestad Reglamentaria Regional. El Gobierno Regional. Sus antecedentes, atribuciones y su poder normativo. 2.1. Antecedentes Generales, 2.2. El Gobierno Regional 2.3. La atribución de la potestad reglamentaria y su carácter. 2.3.1. Ambito de competencia de los reglamentos regionales 2.3.2. El grado o jerarquía de los reglamentos regionales. Su inserción en el ordenamiento jurídico. 2.4. Procedimiento de elaboración. 2.5. Control de los reglamentos regionales. 2.5.1. La toma de razón por parte de la Contraloría General de la República. 2.5.2. El reclamo de ilegalidad. 3. La Potestad Reglamentaria Municipal. La Municipalidad: Sus antecedentes, atribuciones y los reglamentos municipales. 3.1. Antecedentes generales, 3.2. Desarrollo del Poder Normativo Municipal. 3.3. La atribución de la Potestad Reglamentaria Municipal y su carácter. 3.3.1. Las Ordenanzas Municipales.3.3.2. Los Reglamentos Municipales. 3.3.3. El Plan Regulador Comunal. 3.3.4. Organos municipales dotados de potestad reglamentaria interna.3.4. Procedimiento de elaboración. 3.5. El control de la potestad reglamentaria municipal. 3.5.1. Aspectos Generales. 3.5.2. Control Interno.3.5.3. Control Externo.

\section{Aspectos generales}

Si el hombre -ser naturalmente social y político- ha de tener un fin, esto no debe ser otro que el bienestar propio y de los suyos, el cual sólo podrá alcanzar en sociedad. De esta manera, su bien individual encontrará plenitud en el bienestar común, del cual también participa.

Por tal razón, el Estado, como creación cultural y humana, se nos aparece como un instrumento al servicio de la persona y con un fin determinado: promover el bien común, el cual comprende la creación de las condiciones de condiciones sociales que permitan a todos y a cada uno de los integrantes de la comunidad nacional su mayor realización espiritual y material posible, dentro del marco de derechos y garantía que la Constitución establece.

El Estado y sus órganos están llamados a desarrollar esta labor ministerial, tanto en su función legislativa, jurisdiccional y administrativa, consagrada así por la norma 
fundamental que los crea: la Constitución Política de la República, y así reafirmada respecto de la Administración en el artículo 3 de la LOCBGAE.

Contemporáneamente la creación del Derecho se ha radicado en un órgano y/o poder específico del Estado: el legislativo, que bajo nuestra CPR se atribuye al Congreso Nacional, sin perjuicio de las facultades colegisladora del Presidente de la Repúbli$\mathrm{ca}^{1}$. Sin embargo, esto no obsta a que el hombre individual o en comunidad cree su propio derecho, siempre dentro de cierto ámbito de licitud, lo cual le otorga a la vez validez a sus normas.

Es así como en el ámbito del Derecho privado se forja la costumbre y los actos jurídicos, particularmente contractuales, como los principales mecanismos de autoregulación jurídica de las personas individuales o morales, pero también, y en el ámbito del Derecho público, se desarrolla una interesante capacidad autonormativa en los órganos de la administración, conocida como potestad reglamentaria. ${ }^{2}$

El propósito de esta trabajo es el análisis de la potestad normativa de dos órganos vitales dentro del proceso de gestión regional y local: el Gobierno Regional y las Municipalidades, a través de los denominados reglamentos regionales y en las ordenanzas y reglamentos municipales, respectivamente.

Pero este objetivo parte de los siguientes presupuestos que es necesario expresar como cuestión previa a su exposición:

a) Los Gobiernos Regionales y las Municipalidades son órganos descentralizados territorialmente, con personalidad jurídica de Derecho público y patrimonio diverso al del fisco. El poder de estas entidades territoriales se extiende sobre la totalidad de la población que encuentra asiento en un territorio predeterminado como límite de su competencia, ya sea la región o la comuna respectivamente.

Las entidades territoriales se caracterizan por la universalidad de sus fines, ya que en principio, nada de lo que afecte los intereses de quienes habitan dentro de su territorio les puede resultar ajeno, lo cual queda de manifiesto ante la lectura de las siguientes disposiciones:

1. Inciso $2^{\circ}$ del artículo 100 de la CPR:

"La administración superior de cada región radicará en un gobierno regional que tendrá por objeto el desarrollo social, cultural y económico de la región."

2. Artículo 13 de la LOCGAR.

1 Facultades que por lo demás son determinante y que hacen que el proceso legislativo queden entregado en nuestro pais al Jefe de Estado a través de dos institutos: la iniciativa exclusiva y la facultad de asignar urgencias a determinados proyectos.

Lo expuesto es sin perjuicio de las potestades normativas que se ejercen a través de circulares e instrucciones, figura bastante cuestionable juridicamente pero poco "discutida" en nuestro país. A este respecto se puede ver nuestro trabajo titulado "Las normas internas: el problema de las circulares e instrucciones", en Revista Anuario N³, 1997, de la Facultad de Ciencias Jurídicas de la Universidad de Antofagasta, pp. 68-73. 
"La administración superior de cada región del país estará radicada en un gobierno regional, que tendrá por objeto el desarrollo social, cultural y económico de ella."

\section{Inciso $2^{\circ}$ del artículo 107 de la CPR:}

"Las municipalidades son corporaciones autónomas de derecho público, con personalidad jurídica y patrimonio propio, cuya finalidad es satisfacer las necesidades de la comunidad local y asegurar su participación en el progreso económico, social y cultural de la comuna."

\section{Inciso $2^{9}$ del artículo $1^{\circ}$ de la LOCM:}

"Las municipalidades son corporaciones autónomas de derecho público, con personalidad jurídica y patrimonio propio, cuya finalidad es satisfacer las necesidades de la comunidad local y asegurar su participación en el progreso económico, social y cultural de las respectivas comunas."

En consideración al carácter universal de los fines que la CPR asigna a las entidades territoriales, es que el legislador les atribuye potestades públicas de la mayor relevancia, como la reglamentaria, la expropiatoria, la tributaria, etc.

Sin embargo, la generalidad de los fines propios de las entidades territoriales bajo ningún aspecto significa la posibilidad de realizar acciones no delimitadas, para adoptar cualquier decisión o utilizar medios no determinados, sino que única y exclusivamente los poderes que en forma tasada y delimitada les atribuyen sus respectivas leyes orgánicas.

Dentro de este marco general, es que trataremos la potestad reglamentaria de los Gobiernos Regionales y de las Municipalidades.

b) Una de las atribuciones y funciones fundamentales de los órganos que tienen a cargo la gestión regional y local es la planificación, a objeto de intervenir en el proceso de cambio social, ya sea para acelerarlo, controlarlo y orientarlo en función de modelo o imagen futura de sociedad en el ámbito de la región y la comuna. En virtud de dicha actividad se determinan los objetivos que se persiguen y los instrumentos más eficientes para alcanzar esos objetivos. Estos instrumentos pueden ser de diversa naturaleza, pero nos interesan aquellos que emanan de potestades atribuidas por el ordenamiento jurídico ( $\mathrm{v}$. gr. sancionatoria, impositiva y expropiatoria.), en particular la potestad normativa de las entidades territoriales.

La norma jurídica, y en particular aquella de origen legal o reglamentario, es ante nada, un proyecto de convivencia que se transmite a sus destinatarios en forma solemne, en otras palabras, es organizar el futuro, planificando, conformando o configurando las condiciones de vida social.

La idea de planificación por medio del Derecho supuso una acentuada confianza en la potencialidad calculadora y organizativa de la razón humana. Dicha confianza tiene su origen en el siglo de las luces, en el cual se propagó la creencia que el legislador ilustrado (esto es, racionalista) podría utilizar la ciencia al servicio de la organización social. 
Lo cierto es que, si bien el Derecho es un importante instrumento de planificación social, su potencialidad planificadora es más limitada de lo que suponían los iluministas y los entusiastas del legalismo decimonónico.

Como lo señala GREGORıO ROBLES, el Derecho puede configurar la vida futura de la sociedad dentro de los límites que las propias estructuras sociales y la mentalidad social imperante lo permita. Efectivamente, por cuanto, con regular no se arregla todo, ya que los procesos sociales no son moldeables a criterio del legislador o la administración, sino que poseen su propia consistencia, que será tanto más firme cuanto más arraigados se encuentren en la tradición y en los hábitos sociales. ${ }^{3}$

Por tal razón, el gran penalista alemán y filósofo del Derecho MAX ERNST MAYER nos señala que la justificación del Derecho y, en particular, de la obligatoriedad de la ley, radica en que las normas jurídicas están en correspondencia con normas de cultura, cuya obligatoriedad el individuo conoce y acepta, pero sentencia que "el Estado está llamado a promover el desarrollo de la cultura a través de su ordenamiento jurídico; el Derecho debe comportarse frente a la cultura no sólo de manera receptiva, sino también productiva. En consecuencia, ha de suceder que se dicte leyes de las que resulten para el individuo nuevos deberes, de las que deriven exigencias que sólo pueden ser conocidas a partir de la ley misma... la legislación debe abrir camino a los progresos culturales, y no puede, en consecuencia, quedarse detenida en lo arraigado. Es una de las tareas más difíciles de la legislación hallar el justo medio entre el apego a las normas existentes y la educación del pueblo orientada hacia nuevas directrices." 4

En este sentido, el ejercicio de la potestad normativa territorial constituye un importante instrumento en la estrategia regional y comunal de desarrolla, como también de desarrollo cultural, en cuanto sea utilizado adecuadamente en pos de tales fines.

b) Tanto la potestad reglamentaria regional como la municipal se ejercen dentro del ámbito de la función de administración en la región y en la comuna. En efecto, si bien el Estado de Chile es unitario, para los efectos del gobierno y administración interior el territorio de la República se divide en regiones, y éstas en provincias. Para el sólo efecto de la administración local, las provincias se dividen en comunas (artículo 99 (PR). La función de gobierno al interior del Estado, por tanto, se proyecta orgánicamente sólo a nivel regional y provincial, mientras que la función de administración alcanza además a las comunas.

Para el cumplimiento de estas funciones, la administración del Estado adopta diversas formas organizacionales a nivel territorial, a fin de encomendar a órganos diversos el cumplimiento de tales tareas. En general, la función de gobierno se realiza a través de órganos desconcentrados de la administración central, cuyo titular es de la exclusiva confianza del Presidente de la República, ejercidas por el intendente a nivel regional y los gobernadores a nivel provincial.

3

Robles, Gregorio: Sociología del Derecho, Editorial Civitas, S.A., primera edición, Madrid, 1993, pp. 161-163.

4 MAYER, MAX ERNST: Rechtsnormen und Kulturnormen. Wissenschaftliche Buchgesellschaft, Darmstzadt, 1965 [reimpresión inalterada de la edición de Breslau, 1903]. 
En cambio, la función de administración se realiza, por regla general, a través de órganos descentralizados territorialmente, salvo a nivel provincial, que es ejercida por la gobernación, órgano territorialmente desconcentrado del intendente (artículo 105 CPR y artículo 3 LOCGAR).

Nuestra CPR establece que la función de administración será realizada a nivel regional por una entidad denominada Gobierno Regional, mientras que en el ámbito comunal esta corresponde a las Municipalidades. De esta manera la atribución de la potestad reglamentaria es esencialmente administrativa, y su ejercicio se enmarca dentro de dichos límites. No se puede concebir la atribución de esta potestad normativa como una suerte de creación de parlamentos regionales o comunales, por cuanto en su ejercicio deben sujetarse al principio de legalidad, que comprende no sólo la CPR sino que además la ley, la que sólo deben ejecutar administrativamente en el ámbito de su competencia administrativa.

\section{La Potestad Reglamentaria Regional}

El Gobierno Regional. Sus antecedentes, atribuciones y su poder normativo.

\subsection{Antecedentes Generales}

Si bien la potestad reglamentaria presidencial y municipal adquirieron delineamientos claros y precisos ya en el siglo pasado, y se configuraron como fuentes pródigas en la producción normativa nacional, la existencia de un poder reglamentario en un nivel territorial intermedio careció de la suficiente fuerza política para su consagración. De hecho, esta posibilidad era consecuencia necesaria a la creación de entidades que descentralizaran la administración estatal.

La existencia de grandes centros territoriales abarcados bajo la forma jurídica de regiones o provincias, siempre dejaba latente la idea de crear órganos de administración autónomos, dotados entre otras facultades de un poder de autoadministración y normación. Sin embargo, una potestad normativa de estas características generaba ciertas reparos y opiniones encontradas, centradas básicamente en el carácter unitario que el país había asumido en 1833 y ante todo la posibilidad, por pequeña que fuera, de contradecir a un fuerte poder central impulsor de toda acción política hacia las regiones. Muchas fueron las intenciones, pero también desilusionantes los resultados al momento de hacer su efectiva aplicación

Fue en la Constitución de 1925 donde aparece el primer atisbo de crear un fuerte poder en las provincias a través de las Asambleas Provinciales, que eran órganos asesores y también deliberantes, de generación indirecta, pero que carecieron de vigencia efectiva ante la no aprobación por parte del legislativo de las normas necesarias para su establecimiento.

Con la entrada en vigencia de la Constitución de 1980 tampoco se apreciaron avances sustanciales. El Gobierno y la Administración interior se encomendaba a órganos que a nivel regional gozaban de una escasa autonomía, debido a su carácter desconcentrado y su generación no representativa. 
No fue sino hasta la dictación de la Ley de Reforma Constitucional № 19.097, en que se dio un gran avance en la descentralización territorial a nivel regional. Fue de esta forma como surgieron los Gobiernos Regionales.

El siguiente paso fue un perfeccionamiento y adecuación de la legislación a las disposiciones constitucionales reformadas y al nuevo ambiente centrado en potenciar la descentralización del país. Esto se concretó en la Ley Orgánica Constitucional sobre Gobierno y Administración Regional № 19.175 (LOCGAR), la cual regula detalladamente las atribuciones de los órganos de gobierno y administración regional y provincial, dando origen a la potestad reglamentaria regional.

\subsection{El Gobierno Regional}

Conforme al artículo 100 de la CPR, el Gobierno de cada Región reside en el intendente, y su administración superior en un Gobierno Regional que tendrá por objeto el desarrollo social, cultural y económico de la región.

El Gobierno Regional es una entidad descentralizada territorialmente, razón por la cual goza de personalidad jurídica de derecho público y de un patrimonio propio (inc. final artículo 100). Los órganos a través de los cuales cumple sus funciones son dos: el intendente, que es el órgano ejecutivo, y el Consejo Regional.

El intendente, además, preside el Consejo Regional y le corresponde la coordinación, supervigilancia o fiscalización de los servicios públicos creados por ley para el cumplimiento de las funciones administrativa que operen en la región, sin perjuicio de las demás atribuciones y funciones que establece la LOCGAR.

El Consejo Regional es un órgano de carácter normativo, resolutivo y fiscalizador, dentro del ámbito propio de competencia del gobierno regional encargado de hacer efectiva la participación de la ciudadanía regional y ejercer las atribuciones que la ley orgánica le encomiende.

\subsection{La atribución de la potestad reglamentaria y su carácter}

El Capítulo II del título II de la LOCGAR, distingue entre las funciones y las atribuciones del Gobierno Regional.

Las funciones pueden ser generales o específicas. A las primeras se refiere el articulo 16 de este cuerpo normativo, respecto de las segundas, estas son detalladas en los artículos 17 en materia de ordenamiento territorial; 18 , en materia fomento de actividades productivas y 19 , en materia de desarrollo social y cultural. Las atribuciones están detalladas por el artículo 20 de la LOCGAR.

La potestad de dictar reglamentos por parte de los Gobiernos Regionales esta enfocada en estos dos aspectos, es decir, como función y como atribución. En general, podemos señalar que las funciones son las tareas o deberes que la ley encomienda el Gobierno Regional con el objeto de propender el desarrollo social, cultural y económico de la región, en cambio las atribuciones, son las potestades o instrumentos jurídicos que el ordenamiento les entrega con el objeto de cumplir estas funciones. Sin embargo, no existe una separación tajante entre estos dos conceptos, cuestión que ya hemos hecho presente en otra oportunidad al señalar que las potestades atribuidas a la Admi- 
nistración son en pos de un interés objetivo, y en tal sentido reciben en doctrina la denominación de potestad - función, de manera que atribución y función se encuentran estrechamente unidas.

En este sentido, la LOCGAR, dentro del conjunto de las funciones generales del Gobierno Regional, la letra d) del artículo 16 le encomienda la de:

"Dictar normas de carácter general para regular las materias de su competencia, con sujeción a las disposiciones legales y a los decretos supremos reglamentarios, las que estarán sujetas al trámite de toma de razón por parte de la Contraloría General de la República y se publicarán en el Diario Oficial"

De igual forma, el artículo 20 atribuye al Gobierno Regional la potestad de:

"Aprobar y modificar las normas reglamentarias que le encomiendan las leyes, no pudiendo establecer en ellas, para el ejercicio de actividades, requisitos adicionales a los previstos por las respectivas leyes y los reglamentos supremos que las complementan".

Ambas disposiciones son las que sustentan la denominada potestad reglamentaria regional, y a la vez señalan su campo o límites de acción y su inserción en el ordenamiento jurídico.

Desde la discusión en torno a la creación de los Gobiernos Regionales, se discutieron los alcances de la facultad normativa que se les otorgaría. Incluso, para algunos, revelaría un principio de desecentralización gubernalmente -no sólo administrativa-, que comprendería tanto al Poder Ejecutivo como al Legislativo, llegándose a postular a los consejos, calificados de órganos normativos por la Constitución Política, como creaciones cercanas a los parlamentos regionales.

Sin perjuicio de la precisión hecha sobre esta materia al inicio de este trabajo, cabe señalar que esta aspiración y la consiguiente cuestión de derecho que involucra fueron, sin embargo, ampliamente superadas. La CPR es clara en relación a la distinción de las potestades de gobierno de la administración y asigna al Gobierno Regional y a sus órganos, participación sólo en la administración.

En consecuencia, y como lo señala CRISTIAN ARÉVALO, no se trata, a través de la facultad reglamentaria regional, de emular la labor legislativa, sino que una función administrativa, la cual ha de encuadrarse, al igual que la potestad reglamentaria del Presidente de la República, en lo que la ley dispone, y además, sometiéndose que los preceptos de los reglamentos del Jefe de Estado señalan, permitiendo, así, la aplicación de la ley y reglamentos respectivos en las condiciones particulares de cada región y en el ámbito de la competencia del Gobierno Regional. ${ }^{5}$

\subsubsection{Su requisitos formales y ámbito de competencia material}

Si hay un aspecto esencial que condiciona a toda norma en cuanto norma es su validez, es decir, en cuanto esta existe como norma y es obligatoria para los sujetos

5 Arévalo, Cristián: Los reglamentos regionales, Seminario de Consejos Regionales, Segunda Región Antofagasta, N³, Serie Seminarios, Universidad de Antofagasta, 1996, p. 21. 
destinarios de la mismas, comprendiendo entre estos a los Tribunales de Justicia llamados a aplicarla. El Derecho como ordenamiento normativo dinámico se preocupa en primer lugar de establecer a su vez la creación de nuevo Derecho, proceso en el cual participa el reglamento regional, de forma tal que su validez esta condicionada a respetar un procedimiento, un contenido y a una autoridad predeterminada para sancionar su vigencia. Estos tres tópicos serán los que examinaremos a continuación respecto de esta potestad:

\section{a) Sobre la habilitación previa legal para su dictación}

Uno de los temas que ha sido objeto de apreciaciones discrepantes concierne a sí, para dictar un reglamento regional, el Gobierno Regional respectivo requiere que una ley, de manera expresa y determinada le encomiende emitirlo.

Al respecto, el profesor OSVALDO OELCKER CAMUS ha señalado que el citado artículo 20 se refiere a reglamentos cuya dictación las leyes encomienden al Gobierno Regional. En otras palabras -según el autor citado- pareciera que la habilitación no es directa, sino que se requiere otra ley que expresamente diga, para una materia en particular, que el gobierno regional la reglamentará, lo cual se vería reafirmado, principalmente, por la ubicación que tiene esta norma, esto es, dentro del artículo que enumera las atribuciones del Gobierno Regional. ${ }^{6}$

En igual sentido se pronunciaría un informe de la División Jurídica del Ministerio Secretaria General de la Presidencia señalado que "el reglamento sólo puede abordar aquellos aspectos que una norma legal, por la vía de la habilitación y remisión previas, le encomienda regular, y que se inserten dentro de la esfera de la competencia asignada por la Ley Orgánica Constitucional respectiva". Dicho informe agrega que "la intromisión del reglamento regional en otras materias, o incluso, en otros aspectos de una materia que los expresamente remitidos, determinaría su nulidad" ?

En un informe de la Asesoría Jurídica del Gobierno Regional de Atacama existen interesantes argumentos en orden a que no es necesaria que una ley encomiende en cada casa la dictación de un reglamento regional, bastando para tal efecto el hecho de conformarse a la competencia entregada por su ley orgánica, en virtud de dos razones:

a) en el proceso legislativo el artículo 16 letra d) fue objeto de un modificación en el Senado, por la cual se establecía que sólo se podía regular los asuntos de su competencia "cuando para ello lo faculte la ley de la materia". Esta modificación fue rechazada por la Cámara de Diputados y descartada por la Comisión Mixta, la cual se pronunció por la proposición de la Cámara baja. En cambio el artículo 20 letra a) también fue objeto de esta limitación por el Senado, pero no fue objeto de reparo similar por la Cámara de Diputados. Ahora bien, para establecer cual de los dos preceptos debe primar, dicho informe se inclina por la primera norma, por cuanto esta fue objeto "de una

OELCKER CAMUS. OSVALDO: "Problemas jurídico-políticos que deben abordarse en el proceso de regionalización", p. 14. presentación hecha en las Jornadas del Programa de Gobiernos Regionales y Universidades organizadas por la Subsecretaria de Desarrollo Regional los días 29 y 30 de Abirl de 1998 en la Universidad de Antofagasta, sobre la "Reforma Regional".

7

Citado por AREVALO, ob. cit. nota 5, p. 21 y 22. 
acabada y expresa discusión entre las Cámaras y requirió del sistema de resolución de conflicto entre las Cámaras"; y

b) el Tribunal Constitucional al pronunciarse sobre la constitucionalidad del proyecto, hizo una prevención general en orden a que las referencia a las "leyes" o a la "ley" debe entenderse a la ley orgánica respectiva, de forma tal que el informe concluye que este pronunciamiento no deja lugar a dudas respecto a que no se precisa de leyes que paulatinamente vayan encomendando al ámbito regional la dictación de reglamentos regionales. ${ }^{8}$

En nuestro estudio sólo hemos encontrado cuatro reglamentos regionales dictado en ejercicio de esta potestad ${ }^{9}$ :

1. El reglamento regional $N^{\circ} 1$ del Gobierno Regional de Atacama, que dicta normas sobre la numeración y publicación de reglamentos regionales, publicado en el Diario Oficial con fecha 1 de febrero de 1996;

2. El reglamento regional $N^{\circ} 2$, del mismo órgano y de la misma fecha de publicación, relativo a la promoción del patrimonio natural e histórico de Atacama, como el diseño de la bandera de la Región y la simbología gráfica;

3. El reglamento regional $N^{\circ} 2$ del Gobierno Regional de La Araucanía, publicado con fecha 17 de diciembre de 1996, sobre la simbología regional a utilizar en publicaciones y obras de dicho organismo; y

4. El reglamento regional del Gobierno Regional de Magallanes y la Antártica Chilena, publicado con fecha 5 de febrero de 1997, sobre símbolos expresivos de identidad nacional.

Respecto de cada uno de estos reglamentos ha tomado razón la Contraloría General de la República, a pesar que se han dictado sin ley específica que los autorice, incluso, sin que exista ley que regule algunas materias sobre las cuales versan.

\section{b) Sobre su ámbito material}

Los reglamentos regionales son normas cuyos efectos exceden al ámbito meramente interno del Gobierno Regional, pudiendo alcanzar a todos los habitantes o miembros de la región.

Si bien del texto de la LOCGAR no aparece con claridad el alcance externo de los reglamentos regionales, esta circunstancias se desprende de la historia fidedigna de este cuerpo legal.

En efecto, desde la presentación del proyecto de LOCGAR y hasta el término de tramitación legislativa en el Congreso Nacional, siempre se distinguió entre una potestad reglamentaria interna u organizativa del Gobierno Regional y otra externa o regional. Así la letra a) del artículo 20 del proyecto de LOCGAR, establecía:

8 Ver pp. 31-33, en Seminario de Consejos Regionales, Segunda Región Antofagasta, N³, Serie Seminarios, Universidad de Antofagasta, 1996.

9 Lo cual es sin perjuicio del reglamento de funcionamiento del Consejo Regional del Gobierno Regional de la Araucanía. publicado en el Diario Oficial con fecha 6 de septiembre de 1993. 
"Para el cumplimiento de sus funciones, el gobierno regional tendrá las siguientes atribuciones:

a) Aprobar y modificar las normas reglamentarias regionales que le encomienden las leyes y las de su organización interna, no pudiendo establecer en ellas, para el ejercicio de actividades, requisitos adicionales a los previstos por las respectivas leyes y los reglamentos supremos que las complementen;"

En tal sentido, las letras b) y c) del artículo 36 del proyecto entregaban al Consejo Regional la aprobación de los reglamentos relativos a todos los aspectos de la organización interna del gobierno regional no regulado por la LOCGAR y la aprobación de los reglamentos regionales. Además, correspondía al intendente someter a aprobación del consejo regional el proyecto de reglamento a que se refería la letra b) del artículo 36 (reglamento interno), sin perjuicio de lo cual la disposición octava transitoria establecía que dentro de los treinta días siguientes a la instalación del Consejo Regional, el intendente debía someter a dicho consejo el proyecto de reglamento a que se refiere el inciso segundo del artículo 27.

El Tribunal Constitucional, en el ejercicio del control obligatorio de constitucionalidad de acuerdo a lo dispuesto en el artículo 82 № 1 de la CPR, y mediante sentencia del 4 de noviembre de 1992, declaró inconstitucional la frase "y las de su organización interna" de la letra a) del artículo 20 del proyecto de LOCGAR. Al respecto el Tribunal señaló:

"...todo lo relacionado con esta materia es propio de ley orgánica constitucional al tenor de lo dispuesto en la parte final del inciso primero del artículo 102 de la Constitución Política, que le encarga ejercer al consejo las atribuciones que la ley orgánica constitucional respectiva le encomienda, la que regulará, además, su integración y organización... en consecuencia, debe eliminarse del artículo 20 letra a) del proyecto remitido la frase que expresa "y las de su organización" (Considerando $3^{\circ}$ y $4^{\circ}$ ).

"Que el hecho de delegar en un reglamento la organización interna del gobierno regional es inconstitucional de acuerdo a lo dispuesto en el inciso primero, parte final, del artículo 102 de la Constitución Política, que entrega la regulación de esta materia a la ley orgánica constitucional en estudio; en consecuencia, el inciso segundo del artículo 27, la letra b) del artículo 36 y la octava disposición transitoria del proyecto remitido son disposiciones inconstitucionales que deben eliminarse de su texto".

Este fallo corresponde a una tendencia jurisprudencial en orden a hacer una interpretación estricta de las materias de ley orgánica constitucional. De hecho, al dictarse la LOCM, no realizó reparo alguno de constitucionalidad de su artículo 27 , norma redactada con iguales alcances que la disposición en comento. Más aún, tampoco realizó reparo alguno a la nueva redacción que le dio la Ley $N^{\circ} 19.602$, de 25 de marzo de 1999, respecto de la cual también ejerció el control de constitucionalidad. ${ }^{10}$

El texto original de dicha norma era el siguiente: "Artículo 27.- La organización interna de la municipalidad, así como las demás funciones específicas que se asignen a las unidades respectivas y su coordinación, deberán ser reguladas mediante un reglamento municipal que para tal efecto dictará el alcalde". El nuevo artículo 27, modificado por la citada 
En definitiva, el Gobierno Regional sólo dispone de una potestad reglamentaria externa, y carece de poder normativo para regular los aspectos de organización y funcionamiento interno, la que deberá suplirse mediante el ejercicio de la potestad organizativa y de mando (jerarquía), a través de las respectiva circulares internas. ${ }^{11}$

Esta potestad reglamentaria regional, a pesar de los términos con que se atribuye, no tiene la amplitud que harían suponer los términos utilizados por la norma, ya que la actividad jurídica de la administración, en cuanto suponga una limitación a la actividad de los administrados sólo pueden encontrar su fuentes en el ejercicio de potestades bien delimitadas.

En primer lugar, las potestades están limitadas por las funciones especificas que el ordenamiento jurídico encomienda a los órganos de la Administración, y que nos indican el área donde podrán ejercerse legítimamente. Si bien el Gobierno Regional tiene como fin general el desarrollo social, cultural y económico de la región, esto no significa una posibilidad ilimitada de acción normativa, ya que la propia LOCGAR nos señala en sus artículos 16,17, 18 y 19 las funciones que le son propias, con un mayor grado de precisión. De manera que integrada esta potestad normativa dentro de este sistema legal, se puede establecer en forma paulatina los márgenes dentro de los cuales es posible el ejercicio de la potestad reglamentaria regional.

De esta forma, las materias sobre las cuales pueden versar los Reglamentos Regionales dicen relación directa con las funciones y atribuciones de los Gobiernos Regionales reguladas en el Capitulo II de la LOCGAR, encauzadas dentro del fin general que le encomienda la propia CPR, que es el desarrollo social, cultural y económico de la región, no pudiendo bajo ningún aspecto establecer, para el ejercicio de actividades, requisitos adicionales a los previstos por las respectivas leyes y los reglamentos supremos que las complementen.

Podríamos citar por vía ejemplar las siguientes materias:

a) El otorgamiento de permisos y concesiones sobre sus bienes, conforme lo establece el artículo 70 letra e) de la LOCGAR, como también respecto de los bienes nacionales de uso público cuya administración determine la ley, según lo prevé el artículo 25 letra $k$ ):

b) En igual sentido se podría regular la destinación de los recursos del Fondo Nacional de Desarrollo Regional (FNDR) y de Inversión Sectorial de Asignación Regional (ISAR); y

c) En cuanto se dicte previamente la ley respectiva, se podría reglamentar la destinación de aquellos tributos que se recauden y que graven bienes o actividades con una clara identificación regional (art. $19 \mathrm{~N}^{\circ} 20$ CPR).

En segundo lugar, cabe mencionar que además de este límite cualitativo o material, existe un límite espacial que corresponde al ámbito territorial dentro del cual son

Ley $N^{\circ} 19.602$ dispone :" La organización interna de la municipalidad, así como las funciones especificas que se asignen a las unidades respectivas, su coordinación o subdivisión, deberán ser reguladas mediante un reglamento municipal dictado por el alcalde, con acuerdo del concejo conforme lo dispone la letra j) del artículo 58."

Véase al respecto nuestro artículo citado en la nota 2. 
competentes los Gobiernos Regionales para regular estas materias, que en este caso es la región.

Sin perjuicio de lo señalado, algunos han entendido que la potestad reglamentaria regional sería residual, es decir, está permitiría al Gobierno Regional regular todos aquellos aspectos tratados en la LOCGAR como funciones de su competencia, en cuanto no esté considerado en las leyes y reglamentos respectivos y tengan por objeto el interés de la Región ${ }^{12}$. Sin embargo, conforme lo establecen los artículos 6 y 7 de la CPR y el artículo 2 de la LOCBGA, en concordancia con el artículo $32 \mathrm{~N}^{\circ} 8,60$ y 100 y 102 de la misma Carta fundamental, las competencias normativas están debidamente asignadas, de manera que no se puede ejercer tales potestad sobre un ámbito residual sin infringir abiertamente las dos primeras normas citadas.

\subsubsection{El grado o jerarquía de los reglamentos regionales. Su inserción en el ordena-} miento jurídico

El ordenamiento jurídico regional es de cierta complejidad por la multiplicidad de fuentes que lo constituyen, y por las relaciones que se producen entre esta diversidad de normas.

En primer lugar, las normas básicas y fundamentales son establecidas por la CPR, en su Capítulo XIII, artículos 100 a 104, desarrolladas por la LOCGAR N²19.175, la cual puede eventualmente ser detallada mediante la potestad reglamentaria presidencial (así lo da a entender la letra d del artículo 16), y por último, y al final de esta escala, nos encontramos con los reglamentos regionales.

Si bien se podría establecer que la LOCGAR opera como norma de cabecera en la creación de un subsistema jurídico regional, lo cierto es que esta construcción competencial se quiebra ante una disposición expresa del articulo 16 de la LOCGAR, la cual señala que estas normas (reglamentos regionales) se dictarán con sujeción a las disposiciones legales y a los decretos supremos reglamentarios, de manera que se ha tratado de establecer una relación jerárquica, sometiendo estas disposiciones a los reglamentos presidenciales, a las leyes y lógicamente que a la CPR.

La existencia de un poder normativo tan limitado puede encontrar varias razones. En primer lugar, la creación del Gobierno Regional es un primer gran intento por establecer una efectiva descentralización administrativa a nivel regional, razón por la cual resulta difícil que de una plumada se entregará un fuerte poder normativo reglamentario a dicha entidad. En segundo lugar, la potestad reglamentaria externa u ordinaria -es decir, aquella que limita la libertad de los ciudadanos- sólo puede encontrar como fuente directa la voluntad de los mismos, y sobre todo descansa en los representantes de la comunidad, lo cual se aprecia en forma debilitada respecto de los Gobiernos Regionales que, dentro de las tres entidades primarias o territoriales, son las únicas que se generan de forma indirecta. ${ }^{13}$

12 Citado por AREVALO, ob. cit. nota 5, p. 27, sin indicación de autor.

13 Al respecto se puede ver SANTAMARIA PASTOR, JUAN ALFONSO: Fundamentos de Derecho Administrativo I, Editorial Centro de Estudios Ramón Areces S.A. Primera reimpresión, enero de 1991, pp. 690-817. 
Por último, es bueno que expresemos algunos reparos en torno a la redacción de esta fórmula jerárquica, que en nuestra opinión carecería de una real vigencia práctica. En primer lugar, estos reglamentos regulan materias de competencia de los Gobiernos Regionales. Bien sabemos que la competencia de esta entidades debe ser regulados a través de su correspondiente Ley Orgánica Constitucional, no cabe otra norma de naturaleza diversa sobre la materia, por tanto, la referencia a la sujeción de la leyes que se hace en esta disposición sólo está vinculada a las leyes orgánicas constitucionales sobre gobierno y administración regional que se dicten ${ }^{14}$. En segundo lugar, bien es sabido que las leyes orgánicas no pueden ser complementadas por la vía del reglamento presidencial. En definitiva, si resulta difícil de sostener la existencia de decretos supremos reglamentarios ejecutivos de la LOCGAR, con menor razón podría afirmarse la existencia de una relación jerárquica entre estas normas y los reglamentos regionales.

Esta situación se debe a que el artículo 16 de la LOCGAR rompe una regla de lógica jurídica en cuanto a que esta forma de atribución permite dictar normas reglamentarias que no están jerárquicamente subordinadas a las leyes y a las normas inferiores que conforman su sistema (entre ellas los reglamentos presidenciales), sino sólo a la norma atributiva de la competencia y a las superiores a ella, operando un desapoderamiento de la función de reglamentar la ley al Presidente de la República e incluso al propio Parlamento, salvo que por otra norma de la misma naturaleza y rango se modifique este precepto. Lo que ha ocurrido es que esta regla se ha impuesto por la simple fuerza de los hechos: en lugar de jerarquía se impone una cuestión de competencia. ${ }^{15}$

\subsection{Procedimiento de elaboración}

En procedimiento de elaboración de los reglamentos regionales se distinguen dos etapas: una interorgánica y otra extraorgánica.

\section{Procedimiento interorgánico.}

Este se realiza al interior del Gobierno Regional. Corresponde al Intendente la elaboración del proyecto del reglamento regional (artículo 24 letra g). Para el efecto, el Intendente contará con la colaboración directa de las Secretarias Regionales Ministeriales (artículo 62), como de las Direcciones regionales o provinciales de los servicios públicos nacionales (artículo 65), sin perjuicio de las respectivas divisiones que.comprende la estructura administrativa, que son la de administración y finanzas y de análisis y control (artículo 68)

14 Lo señalado fue reafirmado por lo demás por el Tribunal Constitucional, el cual al ejercer el control previo y obligatorio de constitucionalidad de la LOCGAR señalo en su considerando $N^{\circ} 36$ "que este Tribunal aprueba la constitucionalidad de las disposiciones que a continuación señala haciendo una prevención general en cuanto a que las referencias a las "leyes" o a la "ley" que en ellas se hacen, deben entenderse a la ley orgánica constitucional respectiva, por ser ésta la encargada de establecer, correspondientemente, las atribuciones y funciones del Gobierno Regional, las del Intendente y Gobernador camo órganos propios del Gobierno Regional y las del Consejo Regional.

15 Lo habitual es que la propia entidad a servicio creado por la ley respectiva sea la llamada a complementarla o reglamentarla. Así ocurre con los reglamentos de las Cámaras, respecto de la LOCCN, y con los verdaderos reglamentos respecto al trámite de toma de razón dictados por la CGR, respecto de la LOCCGR. 
Una vez elaborado el proyecto de reglamento regional, este es propuesto por el propio Intendente al Consejo Regional, al cual corresponde su aprobación (artículo 36 letra b) para lo cual no se requiere un quórum especial.

En esta etapa cobra valor la instancia de las audiencias públicas, con el objeto de que los miembros de la comunidad regional puedan hacer presente sus observaciones al reglamento en elaboración. En tal sentido, tiene un carácter esencial la utilización de medidas de publicidad con el objeto de que la población tenga una participación efectiva en gestación de estas disposiciones, contribuyendo además a revestirla de una mayor legitimidad. ${ }^{16}$

Sin perjuicio de lo señalado, no existe claridad en torno al acto necesario para la sanción del reglamento, es decir, aquél acto que da cuenta de su aprobación y vigencia, sujeto previamente al trámite de toma de razón y de su publicación en el Diario Oficial. El problema consiste en determinar si con la sola aprobación del Consejo Regional este reglamento se entiende sancionado, bastando al efecto la certificación del secretario ejecutivo del Consejo, o se requiere de un acto promulgatorio por parte del Intendente como órgano ejecutivo del Gobierno Regional.

Los reglamentos regionales que se han dictado hasta la fecha, y que hemos detallados anteriormente, han sido sancionados por el Intendente, y la Contraloría General de la República ha tomado razón de los mismo sin alcances o reparos.

Sin embargo, debemos tener presente que la LOCGAR ha señalado específicamente los casos en que los actos de aprobación del Consejo deben estar seguidos de una promulgación del Intendente, v. gr. los planes reguladores comunales e intercomunales, según lo dispone el artículo 24 letra o).

Abonaría esta tesis, lo expresado en el informe de las Comisiones unidas de Gobierno, Descentralización y Regionalización y de Constitución, Legislación, Justicia y Reglamento del Senado el cual expresa:

"c) Asimismo, se ha establecido que sea el órgano ejecutivo del Gobierno Regional el que tenga la facultad de proponer al Consejo Regional los Proyectos de Reglamentos regionales que regulan materias propias del Gobierno Regional, en conformidad a las leyes y a los reglamentos supremos correspondientes. Esto es así, por cuanto el Intendente y su gabinete regional poseen los recursos y antecedentes necesarios para fundamentar las proposiciones que deben normar el Consejo Regional. Se puede concluir que es el Consejo Regional donde radica fundamentalmente el ejercicio de la facultad normativa que señala el art. 102 de la Constitución.

"El Intendente, sólo puede proponer, pero jamás regular, sin la aprobación del Consejo, materias que sean propias del ámbito normativo de los Gobiernos Regionales, apruebe la propuesta podrá existir norma reglamentaria regional, con lo cual se refuerza aún más el hecho de que es precisamente dicho Consejo el que resuelve en esta materia"

Por está razón resulta de interés el Reglamento del Funcionamiento del Consejo Regional del Gobierno Regional de la Araucania, publicado en el Diario Oficial con fecha 6 de septiembre de 1993, el cual en su Título XXII, arts. 55 y 56 , regula las audiencias públicas. 
Reafirma lo expuesto el conocido principio de juridicidad de los actos de la Administración: no existen potestades ni atribuciones sino han sido están conferidas por el ordenamiento jurídico, y si se revisa el catálogo de atribuciones del Intendente, no aparece como facultad del mismo la de promulgar los reglamentos regionales (artículos 6 y 7 (PR, 2 LOCGAR).

Lo expuesto daría a entender que el respectivo acuerdo del Consejo Regional sería el acto sancionatorio respecto a la vigencia del reglamento regional, el cual debería ser sometido al trámite de toma de razón por parte de la Contraloría y después publicado en el Diario Oficial.

\section{Procedimiento extraorgánico}

Terminada la elaboración del reglamento por parte del Gobierno Regional este debe ser remitido para su toma de razón por la Contraloría General de la República.

Habiéndose tomado razón del reglamento este es devuelto al Gobierno Regional para su publicación en el diario oficial, fecha a partir de la cual comienza a tener vigencia.

\subsection{Control de los reglamentos regionales}

El Gobierno Regional, como todo órgano de la administración del Estado, debe conformar su acción a la Constitución y a las leyes (artículo 6 y 7 CPR y artículo 2 LOCGAR). Es la Constitución y su respectiva ley orgánica la que le entregan un conjunto de atribuciones y le señalan el marco de actuación donde podrán ejercerlas. Cualquier exceso conlleva necesariamente la actuación de los mecanismos jurídicos a fin de evitar la vigencia de los actos ilegales.

En esta sección nos interesa tratar dos mecanismos de control establecido expresamente por la LOCGAR, tanto de naturaleza administrativa como jurisdiccional, sin perjuicio de los controles generales vistos en la primera parte de este trabajo. Estos son la toma de razón y el reclamo de ilegalidad.

\subsubsection{La toma de razón por parte de la Contraloría General de la República}

El control administrativo por excelencia en nuestro país se realiza por la Contraloría General de la República, órgano que perteneciendo a la Administración del Estado (Artículo $1^{\circledR}$ inc. 2 LOCBGAE), goza de autonomía constitucional.

Dentro del control jurídico, como los hemos mencionado, destaca el denominado control de legalidad a través del mecanismo de "toma de razón", que se ejerce por regla general respecto de todos los decretos y resoluciones emanados de los órganos de la administración del Estado. Sólo por excepción, la ley o una resolución de la propia CGR pueden establecer que ciertos actos queden exentos de dicho trámite. ${ }^{17}$

17

La Resolución NNo 55 de la CGR, de 31 de enero de 1992, sobre exención del trámite de toma de razón, enumera en particular cuáles son resoluciones respecto de las que no es necesario efectuar este trámite. Esta facultad emana del inc. 
Respecto de las resoluciones del gobierno regional no se establece regla de excepción alguna sobre la materia, de manera que sus actos deben someterse a dicho trámite.

La letra d) del artículo 16 de la LOCGAR, establece expresamente la procedencia del trámite de toma de razón:

\section{"Serán funciones generales del gobierno regional}

d) Dictar normas de carácter general para regular materias de su competencia, con sujeción a las disposiciones legales y a los decretos supremos reglamentarios, las que estarán sujetas al trámite de toma de razón por parte de la Contraloría General de la República y se publicaran en el Diario Oficial." (El destacado es nuestro)

Esta disposición, al referirse a normas de carácter general, alude inequívocamente a los reglamentos regionales, los que deberán someterse al trámites allí indicado para que puedan adquirir valor jurídico, constituyendo así una forma de control preventivo de juridicidad realizado por un órgano con autonomía constitucional, sobre tales actos.

En tal procedimiento se puede representar la ilegalidad o inconstitucionalidad de todo o parte del reglamento regional respectivo, ante cuya determinación deberá conformarse el Gobierno Regional y encauzar su actuación de acuerdo a la legalidad vigente, en tal sentido no cabe la insistencia prevista en el inc. 1 del artículo 88 de la CPR e inc. $1^{\circ}$ del artículo 10 de la LOCCGR, ya que esta sólo se establece como facultad privativa del Presidente de la República.

\subsubsection{El reclamo de ilegalidad}

La más importante vía a través de la cual puede reclamarse sobre la validez de los reglamentos regionales la constituye el reclamo de ilegalidad contra resoluciones o acuerdos del gobierno regional.

Este recurso se encuentra establecido en el artículo 102 de la LOCGAR, y en gran parte recoge literalmente al original reclamo de ilegalidad municipal establecido por el artículo $5^{\circ}$ transitorio del D.L. 1,289 , de 1976 , contenido en la actualidad en el artículo 136 de la LOCM.

El reclamo de ilegalidad por actos regionales consta de dos etapas bien delimitadas, una de naturaleza administrativa, iniciada ante el intendente, y otro de carácter jurisdiccional, ante la Corte de Apelaciones respectiva.

\section{Etapa administrativa.}

De acuerdo a esta disposición, las resoluciones o acuerdo ilegales de los gobiernos regionales podrán ser reclamados ante el intendente. Esta reclamación puede ejercerla:

$5^{2}$ del artículo 10 de la LOCCGR

La excepción que se realiza a través de una ley la encontramos en el articula 46 de la LOCM, que establece que las resoluciones que dicten las municipalidades estarán exentas del trámite de toma de razón. 
a) cualquier particular, cuando estas resoluciones o acuerdos afecten el interés general de la región o de sus habitantes;

b) cualquier particular agraviado por estos actos.

En general, todo reglamento regional ilegal, en cuanto norma abstracta y general, afecta el interés general de la región y de sus habitantes, de manera que siempre existirá una acción popular para su impugnación, ya sea total o parcial, la que deberá ejercerse en el plazo de treinta días contados desde la publicación en el Diario Oficial del respectivo reglamento.

Puede ser que además se dicten actos que buscan la ejecución de un reglamento regional ilegal, de manera que se ocasione agravio a particulares, los cuales podrán impugnar el acto de aplicación fundados en la ilegalidad del reglamento, dentro del plazo de treinta días contados desde su notificación.

Estimamos conveniente señalar algunas criticas que nos merece la forma como se ha establecido esta primera etapa en el procedimiento del reclamo de ilegalidad regional, lo cual ha desvirtuado su carácter de recurso administrativo:

1. Esta disposición establece que ante una resolución o acuerdo ilegal del gobierno regional se debe interponer el reclamo ante el intendente, quién bajo ningún aspecto es la autoridad u órgano, que en la materia en estudio, ha dictado el respectivo reglamento regional, razón por la cual no puede entenderse que estemos ante un recurso de reposición, pero tampoco es el superior jerárquico del mismo, por lo cual tampoco estaríamos ante un recurso jerárquico. ${ }^{1 \mathrm{~B}}$

Esta circunstancia es delicada si consideramos que el intendente puede aceptar perfectamente algún reclamo de ilegalidad, dejando sin efecto el respectivo acuerdo o resolución del gobierno regional, sin la más mínima participación del consejo regional.

Más aun, no existe mecanismo alguno que permita al Consejo Regional evitar tales resultados. Tal situación es incluso paradójica, ya que si bien la letra b) del artículo 36 de la LOCGAR, entrega al consejo la facultad de fiscalizar el desempeño del intendente regional, no se establece ninguna consecuencia o instrumento jurídico eficaz que permita controlar su actuar ilegal, limitándose a entregarle la facultad de sólo requerir información necesaria ${ }^{19}$

En tal sentido, estimamos que si bien es el intendente ante quién se presenta el reclamo, este lo recibe en cuanto representante judicial y extrajudicial del gobierno regional (letra h artículo 24), pero deberá dar cuenta de este ante el consejo regional

18 En el reclamo de legalidad municipal (art. 136 LOCM) se puede impugnar toda resolución u omisión del alcalde o sus funcionarios, de manera que concurre ante el alcalde a un recurso de reposición (por actos del alcalde) y un recurso jerárquico (por actos de los funcionarios).

19 La letra g) del articulo 36 de la LOCGAR expresa

"Corresponderá al consejo regional:

g) Fiscalizar el desempeño del intendente regional en su calidad de presidente del consejo y de órgano ejecutivo del mismo, como también el de las unidades que de él dependan, pudiendo requerir del intendente la información necesaria al efecto;" 
para su conocimiento y resolución, dictamen o acuerdo que el propio intendente deberá cumplir como órgano ejecutivo de esta entidad, mediante la correspondiente notificación al reclamante.

2. Se deja fuera del control por vía del reclamo de ilegalidad tanto las omisiones ilegales como los actos de los funcionarios del gobierno regional.

Es perfectamente posible que una ley establezca que sus preceptos sean necesariamente regulados por un reglamento que al efecto dicten los gobiernos regionales, y que estos por omisión no lo dicten y dejen sin aplicación dicha ley ocasionando un daño o perjuicio a particulares. En estas circunstancias tales particulares no podrán reclamar por esta vía de tal ilegalidad ni de los perjuicios causados mediante este mecanismo.

En segundo lugar, cabe además la posibilidad de que, a través de actos de los funcionarios del gobierno regional, se apliquen normas reglamentarias que causen agravio a particulares, quienes tampoco podrán ejercer esta reclamación.

En ambas circunstancias se deberá recurrir a los mecanismos generales, es decir, al ejercicio de las acciones jurisdiccionales ordinarias de nulidad y de plena jurisdicción (artículo 6; 7; 38 inc. 2 de la CPR y artículo 4 y 44 LOCBGAE).

En definitiva, sólo procederá esta reclamación, tratándose de normas reglamentarias por la dictación de reglamentos regionales y por aplicación de sus normas realizada únicamente por el gobierno regional

Cabe mencionar, por último, que el reclamo puede ser aceptado o rechazado, y en este último caso lo puede ser tanto expresa como tácitamente. Se considera rechazado tácitamente el reclamo si el intendente no se pronunciare dentro del término de quince días hábiles, contado desde la fecha de su recepción en la intendencia.

\section{Etapa judicial.}

Esta etapa se abre ante el rechazo del reclamo, expresa o tácitamente. La ley no distingue, pero debe entenderse que este rechazo puede ser total o parcial, correspondiendo en ambos casos la posibilidad de recurrir a la etapa judicial.

Esta reclamación se interpone ante la Corte de Apelaciones respectiva, dentro del plazo de quince días hábiles contados desde la notificación de la resolución que rechace el reclamo o desde el vencimiento del término que tenía el intendente para pronunciarse y no lo hizo, hecho que deberá certificar el secretario de la intendencia regional. El reclamante deberá indicar en su presentación ante la Corte el acto impugnado, la norma legal que estima infringida, la forma como se ha producido la infracción $y$, cuando ello fuere procedente, las razones por las cuales el acto le irroga perjuicio.

La Corte puede dictar una orden de no innovar, suspendiendo los efecto del acto impugnado, cuando su ejecución pueda producir un daño irreparable al afectado. Respecto de esta resolución debemos distinguir:

a. Tratándose de un acto administrativo de aplicación de un reglamento ilegal, el reclamante, ante un inminente daño irreparable, puede solicitar sin mayor problema su suspensión.

b. Tratándose de los reglamentos regionales propiamente tales, se debe distinguir. No se puede decretar con efectos absolutos orden de no innovar respecto de estos 
reglamentos, ya que significaría que su alcance excedería a terceros que no han participado en este procedimiento, al tratar de suspender la aplicación de normas generales aplicables a todos los habitantes de la región. Sin embargo, puede perfectamente el reclamante, respecto de su caso particular, solicitar dicha orden no innovativa, a fin de que a él no se le cause un daño irreparable.

Posteriormente, se dará traslado por el plazo fatal de diez días al intendente. Evacuado el traslado o teniéndose por evacuado en rebeldía, la corte si lo estima necesario, podrá abrir un término de prueba, el que sujetará a las normas de los incidentes. Evacuado el traslado o vencido el término de prueba en su caso se remitirán los autos al fiscal para su informe y a continuación se ordenará traer los autos en cuenta.

De acuerdo a lo dispuesto en la letra h) del artículo 102 de la LOCGAR, la Corte de Apelaciones cuenta con diversos medios para reprimir las resoluciones o actos regionales ilegales, pero que tratándose de reglamentos regionales, estos sólo se limitaran a:

a) la anulación total o parcial del reglamento impugnado;

b) la declaración del derecho a la indemnización de los perjuicios causados, cuando se ha omitido la dictación del correspondiente reglamento, determinado por la ley, y siempre que se hubiere solicitado.

Respecto de un acto que aplica el reglamento ilegal, la administración podrá:

a) anular el acto administrativo y el correspondiente reglamento, ya sea en forma total o parcial;

b) declarar el derecho a la indemnización de los perjuicios causados por la aplicación del reglamento.

Esto es sin perjuicio de remitir los antecedentes al juez del crimen que corresponda, cuando tales hechos sean además constitutivos de delito.

En caso de declararse el derecho a la indemnización de los perjuicios, el reclamante deberá concurrir a los tribunales civiles ordinarios y demandar al gobierno regional en juicio sumario para obtener su determinación y pago.

Por último, debemos señalar que en contra de la sentencia definitiva dictada por la Corte de Apelaciones no procede el recurso de casación.

\section{La Potestad Reglamentaria Municipal} les.

La Municipalidad: Sus antecedentes, atribuciones y los reglamentos municipa-

\subsection{Antecedentes generales}

La CPR sienta los aspectos fundamentales de la administración local, entregando a una ley orgánica la regulación de la organización y atribuciones de las municipalidades.

El constituyente de 1980 otorga a las municipalidades personalidad jurídica de derecho público, señalando expresamente su carácter esencialmente autónomo, en 
cuanto entidad descentralizada territorialmente, dotada de un patrimonio propio y de atribuciones que determina la ley.

El artículo 1 de la LOCM reproduce con algunas precisiones los dos primeros incisos de este artículo. Como entidad jurídica, el municipio actúa en la vida del derecho a través de los siguientes órganos:

\section{El Alcalde.}

Es la máxima autoridad del municipio y le corresponde la dirección, administración superior y la supervigilancia del funcionamiento de la municipalidad (artículo 107 CPR. y 49 LOCM).

\section{El Concejo Municipal.}

Es un órgano deliberante, encargado de dar su acuerdo a los asuntos y materias de mayor relevancia para la comuna, correspondiéndole además funciones normativas, resolutivas y fiscalizadoras.

\section{El Consejo Económico y Social.}

Es un órgano eminentemente consultivo, generado por las entidades comunitarias, gremiales y demás fuerzas vivas de la comuna.

Sin perjuicio de las atribuciones y funciones que le asigna la LOCM, la finalidad de las municipalidades es la de satisfacer las necesidades de la comunidad local y asegurar su participación en el progreso económico, social y cultural de la comuna.

\subsection{Desarrollo del Poder Normativo Municipal}

Un estudio general respecto al desarrollo del Municipio como institución jurídica de administración local nos entrega como dato constante la existencia de un poder normativo radicado en esta entidad vinculado estrechamente a las funciones que el propio ordenamiento jurídico le encomendaba. En efecto, como señala SILVA CimMA el ente autónomo, por esencia, dispone de un conjunto de potestades públicas que le permiten ejercer una acción con independencia, dentro de las cuales se destaca la potestad reglamentaria, puesto que si autonomía significa gobernarse de acuerdo con sus propias normas, es obvio que aquellas normas habrán de ser la consecuencia directa del ejercicio de la potestad referida. ${ }^{20}$

Desde sus origenes, durante el periodo colonial, una de las principales fuentes del Derecho Municipal era la potestad normativa municipal, junto a la costumbre y la voluntad del monarca. Si bien ningún texto legal escrito la consagró expresamente, su ejercicio fue habitual y abundante, basado en el Derecho consuetudinario y de acuerdo a los usos y costumbres. En un comienzo esta potestad normativa se ejerció en forma amplísima, pero posteriormente fue limitada por la Real Audiencia y la Real Ordenanza de Intendentes.

La forma que adoptaron estos actos en la República eran los de simples acuerdos, reglamentos y ordenanzas, conforme los consagró expresamente la ley de 8 de 
noviembre de 1854 en su artículo 103. El criterio de distinción se encontraba en que por las últimas era posible restringir la libertad y la propiedad ${ }^{21}$, es decir, disponían de eficacia ablatoria o externa. Mediante la ley de 9 de octubre de 1861 se estableció con absoluta precisión, respecto de su contenido, las formas de ejercicio de la potestad reglamentaria municipal, distinguiendo claramente cuales resoluciones eran materias de ordenanza, de reglamento o de simple acuerdo. El criterio diferenciador atendía fundamentalmente al hecho de afectar la resolución respectiva al exterior del servicio municipal (ordenanzas) o al interior de este servicio, su patrimonio, personal, oficinas, etc. (reglamentos) y dejando el carácter de acuerdos para las simples resoluciones no comprendidas en las materias propias anteriores. ${ }^{22}$

La Ley de la Comuna Autónoma realizó un cambio en la forma de atribuir la potestad reglamentaria municipal. Si bien mantiene la distinción entre ordenanzas, reglamentos y acuerdos municipales (artículo 83 №4), esta no se realiza sobre la base de las materias que abarcan cada uno de estos tipos de actos. El criterio de distinción se encontraba en la gravedad de las sanciones que pueden imponerse por las ordenanzas ${ }^{23}$, buscando en el fondo limitar la intervención del Ejecutivo eludiendo en lo posible el mandato constitucional que obligaba a la aprobación de las ordenanzas por el Presidente de la República. A parte de ello, la ley orgánica hizo múltiples referencias a las distintas formas de ejercicio de esta potestad al facultar a las municipalidades para "Imponer a las infracciones de las prescripciones municipales penas hasta de cuarenta pesos de multa en decretos o reglamentos, y desde cuarenta y uno hasta setenta pesos de multas en ordenanzas"(artículo $27 \mathrm{~N}$ 1); al primer Alcalde, para "sancionar los decretos que dicte en uso de sus atribuciones hasta con veinte pesos de multa" (articulo 83 №18) y, en general, cada vez que encomienda al municipio "prescribir reglas", "reglamentar", "ordenar", etc. las distintas materias comprendidas en sus atribuciones.

Durante la vigencia de la CPR de 1925, el poder normativo de los Municipios tenía su origen en lo establecido en el artículo 105 del texto fundamental, el cual señalaba en su $N^{2} 6$, que es facultad de ellas formar las ordenanzas municipales sobre las distintas materias que la propia CPR señalaba como facultades propias de los municipios y que, en general, decían relación con la policía de salubridad, comodidad, ornato y recreo: fomento de la educación, la agricultura, la industria y el comercio; cuidado de los caminos, puentes y otras obras de utilidad y ornato que se costeen con fondos municipales, etc. Sin embargo, se mantuvo la forma de atribución a nivel legal que venía rigiendo, tanto en el Decreto Ley №740, publicado el 15 de diciembre de 1925, en sus artículos 49 № 2; 48 №1 y 90 №6, como también en la Ley №11.860, que fijó el texto refundido de la Ley Orgánica Constitucional de las Municipalidades, artículos 55 №2; 54 №1 y 93 №6.

Expresamente el $N^{0} 7$ del artículo 103 de esta ley establecía dentro de las materias de la ordenanza: "En genera! toda resolución que establezca reglas, restringiendo el uso de la libertad personal o el libre ejercicio de una profesión o industria o el libre uso de la propiedad"

22 LARRAIN ZAÑARTU, JOSE JOAQUIN EI Municipio y el Ciudadano, Imprenta Victoria, Santiago, 1888.

23 Silva labbe, Juan Cristobal: La Ley de la Comuna Autónoma, Memoria de Prueba, Universidad Católica de Valparaíso, 1990, p. 40 
Mediante el Decreto Ley 1.289 , de 14 de enero de 1976, se cambia la forma de sistematizar las atribuciones de los Municipios, distinguiendo en el Título I entre aquellas de carácter privativa y compartida (artículo $3^{2}$ ), señalando en su artículo $6^{2}$ que en el ejercicio de sus atribuciones, las Municipalidades gozarán de potestades para dictar resoluciones obligatorias de carácter general. Es en su artículo $13^{2}$ donde se vuelve a recoger la distinción entre ordenanzas y reglamentos. Esta disposición establecía que las resoluciones que adoptará el Alcalde se denominarán ordenanzas, reglamentos, decretos alcaldicios o instrucciones:

"Las ordenanzas serán normas generales y obligatorias aplicables a la comunidad. En ellas podrán imponerse a los infractores multas cuyo monto fluctué entre una unidad tributaria mensual y un máximo de tres unidades tributarias mensuales vigentes en la respectiva comuna. Las ordenanzas que establezcan multas cuyo monto sea superior a tres unidades tributarias mensuales deberán ser aprobadas por el Gobernador Provincial respectivo".

"Los Reglamentos serán normas generales obligatorias y permanentes relativas a materias de orden interno del municipio."

El Decreto Ley 1.289, fue derogado el 31 de Marzo de 1988 por la Ley Orgánica de Municipalidades, № 18.695 , que mantuvo la distinción entre ordenanzas y reglamentos, con pequeñas modificaciones, la cual rige en la actualidad.

\subsection{La atribución de la Potestad Reglamentaria Municipal y su carácter}

La CPR de 1980 no atribuyó, en términos categóricos, la potestad reglamentaria a las Municipalidades. Sin embargo, expresamente se le otorga autonomía a estas entidades y se les confieren facultades normativas a su Concejo, de lo cual se desprende con claridad un mandato constitucional en orden a que el legislador deberá atribuir este poder a los municipios y determinar sus alcances.

Es la LOCM la que precisa la potestad reglamentaria municipal, dentro del párrafo $2^{\circ}$ del Título I sobre "funciones y atribuciones". El artículo 5 letra d) establece que para el cumplimiento de sus funciones las municipalidades tendrán la atribución esencial de dictar resoluciones obligatorias de carácter general o particular. En el artículo 10 se establece una sistematización de estas resoluciones bajo la denominación de Ordenanzas, Reglamentos, Decretos Alcaldicios e Instrucciones. Las dos primeras especies de resoluciones municipales son la manifestación de la potestad reglamentaria municipal, y a cuyo estudio nos abocaremos.

\subsubsection{Las Ordenanzas Municipales}

El término ordenanza es la denominación que se da en general al conjunto de preceptos dictados para el buen gobierno de una ciudad o comunidad. Es decir, es un concepto evidentemente material o sustancial, que alude a un conjunto de normas generales y abstractas sin importar su jerarquía, de manera tal que era posible encontrar en nuestro ordenamiento normas de rango legal bajo esta denominación, v. gr. la Ordenanza General de Aduanas y la Ordenanza General de Construcción, como de rango reglamentario, Ordenanza General de Urbanismo y Construcciones (DS N²47, de 1992 del Ministerio de Vivienda y Urbanismo). 
En sentido estricto, las ordenanzas dicen relación con normas de rango reglamentario emanadas de los órganos de administración local, es decir, de los municipios.

Las ordenanzas están definidas expresamente por la LOCM en el inciso $2^{\circ}$ del artículo 10, como una especie de resolución municipal. Al efecto se expresa que:

"Las ordenanzas serán normas generales y obligatorias aplicables a la comunidad. En ellas podrán establecerse multas para los infractores, cuyo monto no excederá de cinco unidades tributarias mensuales, las que serán aplicadas por los juzgados de policía local".

La Ordenanzas Municipales corresponderían a lo que la doctrina alemana denominaba como reglamentos jurídicos, ya que tienen una eficacia que excede el mero ámbito interno de la administración y se proyecta a la comunidad.

La potestad reglamentaria para dictar ordenanzas es atribuida por la letra d) del artículo 5 en relación con el inc. $2^{2}$ del artículo 10 de la LOCM. Las dificultades que presenta está forma de atribución dicen relación con la amplitud con que se conceden estas facultades normativas, lo cual lleva a dos problemas básicos: la determinación de los límites o ámbito de acción de las ordenanzas municipales y su relación con las disposiciones reglamentarias de otras entidades u órganos.

\section{Su ámbito de acción}

Las ordenanzas cobran un particular interés, dado que sus efectos exceden a la Municipalidad y alcanza a los miembros dę la comunidad local. Bien es sabido que los actos que afectan a los administrados sólo pueden ser productos de potestades bien delimitadas, lo cual es contrario a una atribución en términos tan amplios.

En general, las Municipalidades están destinadas a cumplir la función pública que le asigna la CPR y la ley respecto al conjunto de personas que tienen asiento en la comuna, razón por lo cual los fines que le encomienda la ley son de carácter universal, de manera que "nada de lo que afecte a quienes habitan dentro de su territorio les puede resultar ajeno", de ahí la existencia de una cláusula general que sienta sus fines. Sin embargo, la generalidad de los fines propios de la Municipalidad no significa una posibilidad ilimitada de acción, porque de partida tiene un límite espacial y cualitativo, y porque, en términos particulares, la consecución de esos fines no habilita cualquier decisión o utilización de medios indeterminados, sino que enmarcados dentro de las funciones y poderes específicos atribuidos por la ley. ${ }^{24}$

La función determina el área o sector de intereses públicos en que la municipalidad puede actuar a través de las ordenanzas. En tal sentido, la letra d) del artículo $5^{2}$ y el artículo 10 otorgan en apariencia una potestad reglamentaria amplia, al no señalar límites precisos para su ejercicio, pero que, sin embargo, "una vez integradas a otras disposiciones del sistema legal, admiten ser precisadas paulatinamente hasta llegar a establecer para la potestad contornos mucha más precisos ${ }^{1125}$.

Al respecto se puede ver. PERIVAnCICH, CLAudia y VIDAL, PAZ: "Competencias Municipales", en Municipio. Estudios Jurídicas, Centro de Estudios Públicos y Centro de Estudios y Asistencia Legislativa, 1994, p.51. 
Será el juez, que en el caso concreto, deberá determinar cuando la Municipalidad ha dictado una ordenanza dentro de su competencia y cuando se ha excedido de esta, considerando las materias que son de competencia municipal, es decir las funciones y atribuciones para cuyo cumplimiento han sido dotadas de este poder normativo. De esta forma, las materias sobre las cuales pueden versar las ordenanzas municipales dicen relación directa con las funciones y atribuciones de las Municipalidades reguladas en el párrafo $2^{\circ}$ del Título I de la LOCM, encausadas dentro del fin general que le encomienda la propia CPR, que es el de satisfacer las necesidades de la comunidad local y asegurar su participación en el progreso económico, social y cultural de la comuna.

Podemos citar, como un ejemplo de determinación de la materia propia de las ordenanzas, la sentencia de la Corte de Apelaciones de Santiago, de 30 de marzo de 1994, ratificada por la Corte Suprema en resolución de 2 de mayo de 1994, por la cual se resuelve un recurso de amparo económico impugnando la Ordenanza № 6 de 1993. dictada por la Municipalidad de Recoleta, el cual se aplica al comercio en la vía pública, estacionado, ambulante y ferias en general, que regula y establece requisitos para los quioscos del sector patronato, limitando el giro de estos comerciantes en el rubro vestuario, excluyendo las "parkas, pantalones, camisas, chalecos, vestidos y buzos para adultos", no afectando tal resolución a los comerciantes que se ubican en otra calle de la misma comuna. Estamos claramente ante la regulación de una actividad económica, que de acuerdo al artículo 19 № 21 sólo puede ser regulada por medio de una ley. Al respecto la Corte señaló:

"Limitar la venta en quioscos de ciertos artículos no puede estimarse que prive, perturbe o amenace el derecho a desarrollar cualquier actividad económica, toda vez que no impide el libre ejercicio del comercio por parte de la recurrente, pues dentro de este giro la misma ordenanza autoriza el comercio de innumerables artículos, incluso vestuario de niños.

"La sola exclusión de la venta en la calle de ciertas prendas de vestir para adultos, sólo constituye una forma de reordenamiento para el desempeño de esta modalidad de comercio dentro de la comuna, y con ella se pretende amparar a los comerciantes establecidos."

La Corte, al resolver este recurso, consideró que la cobertura de sus potestades constitucionales y legales eran suficientes para regular esta materia, ya que estas la facultan para reglamentar el uso de los bienes nacionales de uso público ${ }^{26}$. En nuestro criterio nos encontramos ante la regulación de conductas o actividades propias de una relación de sujeción especial de poder, dado por la particular posición que tienen estos comerciantes respecto del municipio, que es el que les otorga los permisos para desarrollar su actividad en bienes nacionales de uso público.

Centro de Estudios y Asistencia Legislativa, 1994, p. 24.

26 Para Bruna Contreras, Guillermo: Amparo Económico. Ordenanza Municipal sabre Comercio, Informe Constitucional $N^{2} 811$, p.3. la municipalidad no puede regular una actividad económica a través de una ordenanza municipal. Según este autor, la Municipalidad y ninguna autoridad que no sea le Organo Legislativo, pueden regular actividades económicas, simplemente por que la Constitución lo dice así (artículo $19 \mathrm{~N}^{2} 21$ y 26). 
En general, si bien las ordenanzas exceden al ámbito interno del municipio, se refieren habitualmente a materias propias de las relaciones de supremacía especial. En un catastro de Ordenanzas Municipales dictadas en los últimos diez años, podemos citar entre las materias más importantes y que con mayor frecuencia son objeto de estos cuerpos normativos los siguientes:

- Servicio de aseo y ornato de la ciudad;

- Derechos por los diferentes servicios que prestan los municipios a la comunidad local;

- Funcionamiento de ferias libres y mercados;

- Las que regulan el transporte y tránsito público en la comuna en armonía con las normas técnicas que dicte el Ministerio de Transporte, etc.,

- Sobre concesiones, permisos y servicios municipales;

- Las que regulan y sancionan los ruidos molestos;

- Sobre extracción de áridos;

- Diseño y construcción de áreas verdes; y

- Sobre propaganda y publicidad.

De manera tal, que su eficacia o proyección hacia toda la comunidad quedaría limitada a este conjunto de materias. En los casos en que la municipalidad regule directamente materias de eficacia ablatoria o que limiten derechos de los habitantes de la comuna, fuera del ámbito de las relaciones de sujeción especial, bajo ningún aspecto pueden considerarse como actos realizados en ejercicio de potestades autónomas, sino que una reglamentación realizada por expreso llamamiento o atribución legal. por ej. así ocurre respecto de las Ordenanzas del Plan Regulador Comunal destinadas a aplicar las normas sobre construcción y urbanización de la comuna con armonía con las normas de carácter general sobre la materia.

Por último, se debe señalar que la LOCM faculta a las Municipalidades para establecer multas a los infractores de las ordenanzas, cuyo monto no podrá exceder de cinco Unidades Tributarias Mensuales, las que serán aplicadas por los Juzgados de Policía Local respectivos. ${ }^{27}$

27 Esta es una de esas normas que goza de mayor tradición, pero que envuelve un serio peligro en torno a la atribución que confiere, por cuanto se atribuye por la vía de una cláusula general de habilitación una potestad administrativa sancionatoria, sin determinar los supuestos de hechos que pueden ser objeto de sanción, los cuales quedan entregados al parecer del órgano administrativo municipal, lo cual vulnera no sólo el principio de legalidad, sino que su manifestación más especifica que es el de la tipicidad de las sanciones administrativas. El desarrollo de esta cuestión excede a lo que se está analizando en este articulo, $y$ a pesar de la inexistente bibliografia sobre el punto, existe una interesante bibliografía nacional sobre el tema de la sanción adiministrativa en general, pudiendo verse ARós TICA MALDONADO, IVAN: "Un lustro de Sanciones Adiministrativas", Revista de Derecho Público, N50, Diciembre, 1991, pp, 173-195 y del mismo autor "Algunos problemas del Derecho Administrativo penal", Revista de Derecho y Jursiprudencia, Tomo LXXXV, Nº $1, p p .41$. 51, 1988: SOTO KLOSS, EDUARDO: "Notas para el estudio de la potestad sancionadora de la Administración", Boletín de Investigaciones, Pontificia Universidad Católica de Chile, año VI, N44. Diciembre de 1979, pp.95-103: ENDREs G., SERGio: "Naturaleza de las Infracciones y Sanciones Tributarias", Gaceta Jurídica, 1997, pp. 23-35. En la bibliografia 


\section{La relación con otras normas reglamentarias}

Por la amplitud de las materias que pueden comprender las ordenanzas municipales, es perfectamente posible que estas puedan entrar en conflicto con otras normas de rango reglamentario, emanadas ya sea del poder central o de otras entidades autónomas.

Aplicando los criterios de inserción de las normas reglamentarias tratado en el Capitulo anterior, debemos determinar, de acuerdo al inciso $1^{\circ}$ del artículo 7 de la CPR, si se han dictado dentro del ámbito de competencia de la respectiva municipalidad u órgano de la administración y en tal sentido se debe hacer primar la norma reglamentaria que emana del órgano que es competente respecto de la materia en cuestión e inaplicar la norma dictada sin la correspondiente habilitación. Pero si ambas entidades gozan de cobertura legal para dictar los respectivos reglamentos debe hacer primar aquella que alegue una atribución específica y determinada, frente a la que detenta un poder general y amplio (normalmente la municipalidad).

Bajo ningún aspecto pueden aplicarse reglas de jerarquía, salvo que la ley expresamente lo establezca, v. gr. LGUC.

En definitiva, las ordenanzas municipales se dictan en ejercicio de potestades tasadas, y gozan de una vigencia exclusivamente local. Por aplicación del principio de legalidad y conforme a la jerarquía del ordenamiento, es indudable que estas ordenanzas deben sujetarse a la CPR, a la LOCM y a las demás leyes vigentes sobre los temas que se aborden en ellos, sin poder entrar a regular campos propios de esos cuerpos normativos. ${ }^{28}$

\subsubsection{Los Reglamentos Municipales}

Los Reglamentos municipales, de acuerdo al inc. 3 del artículo 10 LOCM, son normas generales, obligatorias y permanentes, relativas a materias de orden interno de la municipalidad.

Los Reglamentos Municipales corresponden a los denominados reglamentos administrativos, y tienen por exclusivo objeto la disposición de los recursos humanos y medios físicos que constituyen la organización municipal, la regulación de sus relaciones recíprocas y la dirección de su funcionamiento, a fin de que resulte óptimo el cumplimiento de sus funciones, atendidas las particularidades de la comuna.

Esta potestad normativa está estrechamente vinculada a la potestad organizativa que le corresponde al alcalde, como máxima autoridad de la municipalidad, expresamente establecida en la letra b) del artículo 56 de la LOCM, según la cual el alcalde tendrá la atribución de establecer la organización interna de la municipalidad.

Esta atribución se ejerce mediante la dictación de un reglamento municipal, que tiene por objeto regular la organización interna de la municipalidad, así como las demás

española reciente destaca la obra de NIETO, ALEJANORO: Derecho Administrativo Sancionador, Editorial Tecnos S.A.. 1993.

DE LA FUente, ob. cit. nota 23, p. 40. 
funciones específicas que se asignen a las unidades respectivas y su coordinación (artículo 27), sujetándose a ciertas normas en torno al número y funciones de las unidades municipales, considerando la población que registre la comuna ${ }^{29}$.

Particular interés en cuanto al alcance o extensión de las materias que pueden ser reguladas mediante estos cuerpos normativos, dice relación con las denominadas relaciones especiales de sujeción o supremacía especial. En efecto, existen un conjunto de materias que se encuentran en una suerte de posición intermedia entre la organización administrativa y la comunidad. Se refiere a aquellos casos que denotan una mayor cercanía o vinculación del administrado en una serie de asuntos de interés comunal encomendados a la Municipalidad, ya sea a través de permisos, concesiones o por administración.

Este conjunto de materias en los cuales el administrado entrarían en una esfera de mayor influencia por parte de la Municipalidad autorizaría a ésta para establecer limitaciones sin necesidad de apoderamiento legal específico, ya que esta esfera es cubierta mediante una extensión de la potestad organizativa que estamos tratando.

Sin embargo, en la práctica este tipo de relaciones se regula por ordenanzas, dejando los reglamentos para los aspectos estrictamente internos. Sin embargo, la Ley $N^{\circ} 19.602$ incorporó un nuevo artículo 58 bis, el cual establece que cada Municipalidad deberá disponer de un reglamento de contrataciones y adquisiciones, aprobado por el concejo a propuesta del alcalde, en el cual se establezcan los procedimientos de resguardo necesarios para la debida objetividad, transparencia y oportunidad en las contrataciones y adquisiciones que se efectúen.

\subsubsection{El Plan Regulador Comunal}

Una de las materias de mayor importancia y que es objeto de regulación a través de la potestad reglamentaria municipal es la planificación urbana de la comuna, inmersa dentro de un proceso de planificación que se efectúa para orientar y regular el desarrollo de los centros urbanos en función de una política nacional, regional y comunal de desarrollo socioeconómico. Esta función municipal es de carácter privativa, de conformidad a la letra b) del artículo 3 de la LOCM. Su importancia es tal que nuevo artículo 5 A de la LOCM, incorporado por la Ley $N^{\circ} 19.602$ establece que la gestión comunal contará entre otros instrumentos con el plan regulador comunal.

Esta regulación se concreta en un reglamento denominado plan regulador comunal, que es un instrumento constituido por un conjunto de normas sobre adecuadas condiciones de higiene y seguridad en los edificios y espacios urbanos, y de comodidad

29 En efecto, en aquellas comunas con más de cien mil habitantes deben contar con todas las unidades internas establecidas en la ley, según lo dispuesto en los arts. 13 y 14 de la LOCM: además, estas municipalidades podrán crear otras unidades, en la medida que sus necesidades así lo justifiquen. En tanto, la única unidad interna que obligatoriamente debe existir en las comunas de menos de cien mil habitantes es la Secretaria Comunal y en este tipo de comunas, al parecer no cabria otra cosa que tender a la creación de las unidades enumeradas por la ley, antes de hacer uso de la atribución de crear otras. 
en relación funcional entre las zona habitacionales, de trabajo, equipamiento y esparcimiento. $^{30}$

El Tribunal Constitucional, en sentencia de 25 de enero de 1993, sobre constitucionalidad del Decreto Supremo № 66, del Ministerio de Vivienda y Urbanismo, de 19 de junio de 1992, que aprobaba el Plan Regulador Intercomunal La Serena-Coquimbo, señala expresamente el carácter reglamentario de los planes reguladores por ser de aplicación general, emanan de la autoridad ejecutiva y no se agotan con su cumplimiento. ${ }^{31}$

La legislación vigente sobre la materia la encontramos en la Ley general de Urbanismo y Construcción (LGUC) D.F.L N²458, de 1976, del Ministerio de Vivienda, reglamentada por la Ordenanza General de Urbanismo y Construcción, D.S. NN247, de 19 de mayo de 1992, del mismo Ministerio.

De acuerdo al artículo 44 de la LGUC, el estudio y aprobación del plan regulador comunal, así como sus revisiones, reactualización y modificaciones posteriores, se efectuarán de acuerdo a las disposiciones de esta ley y con las normas para confección de planes reguladores que establezca el Ministerio de Vivienda y Urbanismo. Esta remisión, en lo que respecta al procedimiento de aprobación, debe ser coordinado con las normas respectiva de la LOCM y la LOCGAR.

El procedimiento de elaboración y aprobación del plan regulador consta de varias etapas:

1. El estudio y elaboración es realizada por la municipalidad respectiva de acuerdo a un procedimiento interno compuesto de varias sub etapas. En general, son elaborados por la Dirección de Obras debiendo contar con la aprobación del Alcalde y del Consejo Municipal. El proyecto debe exponerse al público con el fin de que los interesados presenten las observaciones del caso en un plazo de 15 días.

2. Aprobado el proyecto por el concejo municipal, este debe ser sometido a la consideración de la respectiva Secretaria Regional Ministerial de la Vivienda.

3. Una vez que ha sido aprobado por dicha Secretaria o en caso de que esta informe desfavorablemente, debe ser enviado al gobierno regional para su aprobación (artículo 20 letra f) LOCGAR) ${ }^{32}$, el cual dirimirá la controversia.

4. Aprobado por el gobierno regional, la Contraloría General de la República toma razón de esta resolución.

5. Una vez que se ha tomado razón de ella, la resolución que aprobó el plan debe ser publicada en el diario oficial en forma integra, y un extracto de la misma debe ser publicado en un diario de la comuna.

30 Véase: MikEL, MARTIJA M: "Planificación del desarrollo y planes reguladores comunales", en El Municipio. Estudios de Gestión, CEAL CEP, p. 29 a 33, mayo de 1994, y COLIGNON KOMPEN, MAURICIO: Los Planes Urbanisticos como Instrumentos Juridicos en la Planificación del Territorio, Memoria de prueba para optar al grado de Licenciado en Ciencias Juridicas y Sociales de la Universidad Católica de Valparaíso, 1990.

31 Esta sentencia se puede ver en la RCHD, Vol. $20 \mathrm{~N}^{2} 1$, enero-abril 1993, p. 119.

32

El artículo 43 de la LGUC. 
6. El plano, posteriormente, debe ser archivado en las oficinas del Conservador de Bienes raices respectivo.

A través de este procedimiento se entrega al gobierno regional el ejercicio de un importante medio de control preventivo sobre la materia, sin perjuicio de los controles externos respectivos que controlan el accionar de este último, tanto por vía de reclamo de ilegalidad como de toma de razón.

\subsubsection{Organos municipales dotados de potestad reglamentaria interna}

La CPR contempla la existencia en cada municipalidad de un Concejo municipal y de un Consejo Económico y Social, órganos a los cuales la LOCM les encomienda la realización de cometidos específicos, entregándole los correlativos poderes jurídicos que sirven para su realización. Tales entidades, junto con el alcalde, se vinculan interorgánicamente a fin de cumplir con los cometidos generales de la municipalidad, pero también se desarrollan a su interior una serie de relaciones que deben ser reguladas a fin de contar con un parámetro o pauta objetiva de actuación, de manera que la propia LOCM les atribuye una potestad organizativa que se ejerce mediante la dictación de un reglamento de funcionamiento interno.

\section{a. El Concejo Municipal}

El Concejo municipal, conforme al artículo 78 de la LOCM, tiene la atribución de determinar en un reglamento interno las normas, que fuera de lo dispuesto en la LOCM, sean necesarias para su funcionamiento, entre las cuales establecerá especialmente aquellas que regulen las audiencias públicas.

Este poder normativo esta delimitado a la dictación de disposiciones internas exclusivamente necesarias para cumplir las funciones que la LOCM le encomienda, no pudiendo establecer otros poderes, derechos $u$ obligaciones diversos a los previstos en este texto legal orgánico. En este sentido lo ha entendido también la CGR, la que ha señalado que no es posible establecer por la vía del reglamento otros derechos u obligaciones para el concejo, sus miembro o demás órganos o funcionarios de la municipalidad, que los contemplados en la ley municipal.

La doctrina expuesta ha sido aceptada también por la jurisprudencia del Tribunal Constitucional, en orden a que el reglamento del Concejo deberá complementar las normas legales relativas a su funcionamiento que así lo ameriten, pero jamás superar su alcance o contradecirlas. ${ }^{33}$

En cuanto a las audiencias públicas, se ha entendido que estas corresponden a las sesiones, ordinarias o extraordinarias, en que el concejo atiende directamente a personas naturales o jurídicas que tienen interés en efectuar planteamientos particulares ante el órgano. De esta manera no puede afirmarse que, por el carácter público de las sesiones del Consejo, se este cumpliendo efectivamente con una audiencia pública, ya que la primera es de un carácter más restringido que la segunda, en cuanto da dere- 
cho para que cualquier persona pueda asistir a las sesiones ordinarias o extraordinarias, pero $\sin$ la posibilidad de hacer planteamiento alguno, por carecer de derecho a voz.

\section{b. El Consejo Económico y Social Comunal}

El Consejo Económico y Social es un órgano esencialmente consultivo y no vinculante en sus resoluciones respecto a las decisiones que adopta en alcalde, lo cual ha sido objeto de permanente crítica, sobre todo considerando la respresentatividad de que goza. Su composición es compleja, y surge de una diversidad de sectores o áreas organizadas de la comunidad local.

El funcionamiento básico del Consejo está regulado por la LOCM, sin perjuicio de lo cual el artículo 96 establece que esta propia entidad determinará las normas necesarias para su funcionamiento, estableciendo expresamente que sus sesiones serán públicas. La frase "normas necesarias" da a entender que sólo deben tener por objeto hacer operativas las disposiciones que establecen sus funciones $\mathrm{y}$ atribuciones, $\mathrm{y}$ en tal sentido no pueden excederse de este marco legal dado. En tal sentido, encontramos en su ejercicio los mismos márgenes ya fijados o establecidos para el Concejo municipal.

\subsection{Procedimiento de elaboración}

Los reglamentos municipales nacen a la vida del derecho bajo la forma de ordenanzas o de reglamentos propiamente tales, cuyo procedimiento de elaboración no varia sustancialmente, sino sólo en cuanto al mecanismo de la publicación de sus normas en caso de tratarse de la primera categoría.

La LOCM no prevé un procedimiento expreso con el objeto de dar forma a las ordenanzas y reglamentos, sólo se encarga de establecer los órganos que los sancionan.

La iniciativa de las ordenanzas y reglamentos municipales le corresponde al alcalde quien, en su elaboración y atendiendo a las materias de que se trate, contará con la asistencia de las respectivas unidades municipales (desarrollo comunitario; obras municipales; aseo y ornato; tránsito y transporte público; administración y finanzas; asesoría jurídica ), sin perjuicio de poder recabar la opinión que sobre la materia tenga el Consejo Económico y Social Comunal (letra c) artículo 93). Esta primera etapa termina con la elaboración del respectivo texto reglamentario el cual es aprobado por el alcalde.

El texto aprobado por el alcalde debe ser sometido al acuerdo del Concejo municipal para su aprobación (letra j) artículo 58). En esta etapa se logra establecer un mecanismo que permite a la comunidad contar con un grado de participación en la sanción de estas disposiciones locales, por dos razones básicas: la generación democrática de los miembros del Concejo y por las audiencias públicas, que en su reglamento interno el Concejo debe considerar. Será en esta última instancia donde la comunidad organizada podrá hacer valer sus puntos de vistas respecto a la normativa en elaboración, sin perjuicio de lo cual el propio Concejo puede además solicitar el dictamen del Consejo Económico y Social Comunal ( letra c) artículo 93).

Obtenido el acuerdo del Concejo municipal, el alcalde puede hacer uso de la atribución concedida en la letra i) del artículo 56 , y proceder a aprobar la correspondiente ordenanza o reglamento municipal. 
Por último, tratándose de una ordenanza, debe proceder a su publicación.

A pesar que dentro de esta enumeración de formalidades aparezca la publicación como una medida más, ésta verdaderamente cobra la mayor importancia, ya que se constituye en una garantía para los administrados que se verán sujetos a estos nuevos preceptos que emanan de la municipalidad por medio de las ordenanzas, a fin de poder impugnarlas. Es muy decidora la expresión en cuanto a que en el Derecho Público la forma deviene en sustancia y se configura como una garantía para los gobernados. De aquí la importancia de determinar que materias son objeto de ordenanza y de reglamento municipal

\subsection{El control de la potestad reglamentaria municipal}

\subsubsection{Aspectos Generales}

La función y atribuciones de los municipios, como de todo órgano de la administración, encuentra en el ordenamiento jurídico el fundamento y límite de sus actuaciones, lo cual no es sino expresión del principio de legalidad. De esta forma surge la potestad reglamentaria municipal, como manifestación de un poder otorgado por la ley en forma tasada y limitada, que esta unida estrechamente a las funciones que se les encomienda en favor del progreso de la comunidad local.

Para que este principio sea una realidad respecto del ejercicio de la potestad reglamentaria municipal, es necesario contar con un sistema de control que a lo menos cumpla con dos requisitos, en primer lugar, deben servir para constatar y reprimir, de la forma más eficaz, todo acto normativo que escape a los causes de su competencia, en segundo lugar, estos mecanismos de control no deben ser una traba o entorpecimiento para el cumplimiento de las funciones públicas municipales.

Desde un punto de vista histórico, el régimen municipal se ha caracterizado por la existencia de normas expresas en orden a establecer un sistema de control de la actividad municipal, y que han constituido un enorme avance respecto del régimen administrativo general, que de una u otra forma han pasado a constituirse en disposiciones comunes de gran parte de la administración.

En el siglo pasado, la ley de Municipalidades de 1854 contemplaba varios mecanismos de control, de orden interno y externo ${ }^{34}$, como también la Ley de la Comuna

34 Al efecto el articulo 33 establecía un sistema de control administrativo externo: "Si al tomar en consideración un acuerdo municipal para promulgario o para su ejecución. el Gobernador o subdelegado reconoce que es contrario a las leyes o disposiciones vigentes dictadas por autoridad competente que recae sobre materia que no es de la competencia de la Municipalidad, o que ésta ha excedido en él sus atribuciones, o que es notoriamente perjudicial a la localidad, suspenderá la promulgación o ejecución, y lo devolverá con sus observaciones a la Municipalidad para que lo reconsidere. En este caso la Municipalidad para que lo reconsidere. En este caso la Municipalidad necesita para insistir en el acuerdo observado la mayoría de dos tercios de sus miembros presentes. Si la Municipalidad insiste en un acuerdo objetado de ilegal o de haberse celebrado sin competencia, el Gobernador o subdelegado elevará el negocio al Gobierno para que resuelva con acuerdo del Consejo de Estado". El artículo 110 sentaba la norma general sobre la materia al establecer el principio de legalidad en los actos de la municipalidad: "Las ordenanzas, reglamentos y acuerdos municipales no podrán, ningún caso, prevalecer contra lo que dispongan las leyes. Tampoco podrán prevalecer contra las resoluciones de 
Autónoma de $1891^{35}$. Caracterizaba a estos cuerpos legales el otorgamiento de un derecho de acción directo a los ciudadanos que fueran afectados por una resolución ilegal de la municipalidad, con la posibilidad de recabar a una instancia externa, fundamentalmente jurisdiccional, su revisión conforme a la ley.

En general, la LOCM no contempla mecanismos específicos en orden a reprimir los actos reglamentarios ilegales, pero del sistema general de control de la actividad municipal es posible extraer aquellos que significan un mecanismo efectivo de resguardo de la legalidad en el actuar municipa $\left.\right|^{36}$.

El Control puede ser interno o externo, atendiendo a si son efectuados por órganos del propio municipio o por autoridades o entes distintos a él. En este último caso el control puede ser político, administrativo y judicial.

Como ya hemos visto los mecanismos de control general de los reglamentos, corresponde tratar, en esta parte, los órganos que ejercen un control especial sobre los actos reglamentarios de las municipalidades.

\subsubsection{Control Interno}

El control interno es realizado por los propios órganos del municipio, y que de alguna manera intervienen en la configuración de la voluntad de la administración o se encargan de encausarla conforme a la legalidad. En el caso en particular de las ordenanzas y reglamentos, este puede ser ejercido, en orden de importancia, por el Concejo Municipal, la Unidad de Control y la Unidad de Asesoría Jurídica.

autoridad competente sobre el ramo u objetos materias del acuerdo". El artículo 111 estableció expresamente como consecuencia de esta infracción la nulidad unido a un contencioso especial: "La Municipalidades no podrán dictar ordenanzas o reglamentos sobre objetos que no sean especial y determinadamente locales. Los que sobre objetos de otra clase dictaren son nulos, y el Gobernador o subdelegado o el Intendente de la provincia podrán declararlos tales. Si la Municipalidad se entiende competente, podrá reclamar de esa declaración ante el Consejo de Estado". El articulo 112 establece el principio de competencia territorial: "Las ordenanzas o reglamentos de policia de salubridad, buen orden, seguridad, etc, que acordare una Municipalidad, solo surtirán su efecto dentro del departamento o territorio en que la Municipalidad funciones. Las reglas de policía de más general aplicación, relativas a los mismos objetos, serán dictadas por el Presidente de la República, quien procederá de acuerdo con el Consejo de Estado, cuando dichas reglas impusieren a los ciudadanos deberes cuya infracción se sujetará a represión penal". Por último, el artículo 114 establece expresamente un importante antecedente del contencioso especial de nulidad: "Cualquier ciudadano tiene el derecho de reclamar contra los acuerdos o resoluciones municipales dictados sobre negocios que no sean de la competencia del cuerpo, o en que se ha excedido de sus atribuciones, o en que se contraria una ley o disposición dictada por autoridad competente. Si la Municipalidad, ante quien se interpondrá el reclamo, resolviere declarando legal y legitimo el acuerdo, podrá el reciamante recurrir al Consejo de Estado para que resuelva.".

En su artículo 99 se establecía que "Cualquier ciudadano podrá reclamar ante la Municipalidad contra sus resoluciones ilegales. Si la Municipalidad desestimare las reclamaciones interpuestas contra sus resoluciones ilegales, podrá acudirse a la Corte Suprema; la cual se pronunciará breve y sumariamente, y con audiencia del ministerio público".

Respecto al sisterna general de control municipal se puede ver: MAGASICH AIROLA, JUAN: "Control de la Actividad Municipal", en Municipio. Estudios Jurídicos, Centro de Estudios Públicos y Centro de Estudios y Asistencia Legislativa, 1994, p. 135 y ss. 


\section{a) El Concejo Municipal}

El Concejo es un órgano deliberante y fiscalizador, en cuanto ejerce labores de control sobre el alcalde, sobre la ejecución de los acuerdos adoptados, sobre las unidades municipales e indirectamente sobre funcionarios municipales.

Esta función fiscalizadora, en general supone el derecho que le corresponde al Concejo de ser informado de modo permanente respecto de la forma en que el alcalde cumple sus funciones, formulando las observaciones o alcances que estime del caso hacer.

Dentro de las distintas atribuciones relacionadas con la fiscalización, tiene particular interés respecto al ejercicio de la potestad reglamentaria municipal, la posibilidad de controlarla mediante el otorgamiento de su acuerdo obligatorio para la sanción de las ordenanzas y reglamentos, de conformidad a la letra J) del artículo 58 de la LOCM. A través de este mecanismo el Concejo puede ejercer un control no sólo de legalidad sino que también de mérito, dado que está actuación del alcalde requiere de su consentimiento para que nazca a la vida jurídica.

\section{b) La Unidad de Control}

La LOCM se refiere en su párrafo cuarto a la organización interna de los municipios, que en forma genérica esta compuesto por direcciones, departamentos, secciones $u$ oficinas. En las comunas con más de 100.000 habitantes, los municipios deberán incluir en su organización interna, a lo menos la Secretaria Municipal, la Secretaria Comunal de Planificación y Coordinación y las unidades de obras municipales, aseo y ornato, tránsito y transporte público, administración y finanzas, asesoría juridica y control.

La Unidad de Control, regulada en el artículo 25 de la LOCM, tiene entre sus funciones básicas, la de "representar al alcalde los actos municipales, cuando los estime ilegales, para cuyo objeto tendrá acceso a toda la documentación pertinente", realizando una función similar a la CGR respecto del gobierno.

Este control es esencialmente preventivo, es decir, debe realizarce antes que la ordenanza o reglamento municipal nazca a la vida del derecho. Así lo ha entendido la CGR, la cual ha señalado que sería oportuno que el control, atendida su naturaleza, sea efectuado antes que el acto se materialice, para evitar de esta forma que el alcalde incurra en eventuales ilegalidades que, posteriormente irroguen responsabilidad ${ }^{37}$, sin embargo se ha discutido el carácter obligatorio de este dictamen ${ }^{38}$.

${ }^{37}$ Dictamen N0 13.635 de 1989, de la Contraloría General de la República.

38 Al respecto ver: MAGASICH AIROLA, JUAN, ob, cit. nota 252, p. 149: "Algunos autores sostienen, que en este punto, el órgano contralor estaría obligando a efectuar el control a priori, toda vez que la Contraloría estaría interpretando la ley en el sentido expuesto, y sus interpretaciones son obligatoria par la administración pública (art. 6 Ley N 10.336). Sin embargo, no compartimos esta posición por estimar que el dictamen en comento no interpreta la ley, sino que la complementa, razón por la cual usa las expresiones mencionadas. En consecuencia, no es obligatorio para los municipios, sin perjuicio de concordar plenamente con la postura de la Contraloria," 
La Unidad de Control tiene la obligación de representar las ordenanzas y reglamentos ilegales, lo que conlleva necesariamente a una sanción en el evento en que no represente la ilegalidad de algún acto reglamentario, ya sea de carácter pecuniaria o administrativa.

A pesar de la autonomía de las municipalidades y de sus órganos, existe respecto de la Unidad de Control una dependencia técnica hacia la CGR, de acuerdo a lo establecido en el artículo 18 inciso primero de la LOCCGR y del artículo 61 del DL N N 1.263 de 1975. Será este organismo el que podrá dar las pautas generales en el control y representación de las ilegalidades que se puedan cometer en ejercicio de la potestad reglamentaria municipal.

\section{c) La Unidad de Asesoría Jurídica}

En general, la Unidad de Asesoría jurídica tiene por objeto velar por el cumplimiento de los aspectos legales de las actuaciones municipales. En tal sentido le corresponde dar asesoría jurídica al alcalde, informando en derecho respecto de las materias que serán objeto de regulación reglamentaria, dando las orientaciones que sean pertinentes (artículo 24 LOCM).

\subsubsection{Control Externo}

Este control corresponde a órganos externos al municipio, que son de variada naturaleza, así se acostumbra a clasificarlo en control político, administrativo y judicial. En esta sección sólo trataremos estos dos últimos, remitiéndolos a la parte primera respecto al control político.

\section{a) Control Administrativo}

El control administrativo externo corresponde a órganos que perteneciendo a la propia administración, son diferentes y autónomos respecto del municipio.

Como consecuencia del carácter de entidad descentralizada y autónoma de las municipalidades, estos controles sobre los actos reglamentarios son excepcionales, es decir, requieren de una norma expresa que así lo establezca respecto de materias específicas.

En tal sentido, el artículo 44 de la LOCM, exime del trámite de toma de razón por parte de la CGR a las "resoluciones que dicten las municipalidades", estableciendo en su reemplazo un control subsidiario denominado "registro", pero sólo cuando dichos actos "afecten a funcionarios municipales".

Como ejemplos de control administrativo podemos encontrar lo dispuesto en el artículo 20 letra $f$, de la LOCGAR, la cual faculta al gobierno regional, en relación a los municipios ubicados en la región, para "aprobar los planes reguladores comunales e intercomunales, de acuerdo a la normativa que rija en la materia...". Con esta facultad, el gobierno regional ejerce un poderoso control sobre los municipios, toda vez que sus planes reguladores deben ser aprobados por él, es decir, existe un control a a priori o preventivo en esta materia. 


\section{b) Control Jurisdiccional: El reclamo de ilegalidad}

Bien es sabido que el control jurisdiccional respecto de los actos de la administración constituye una de las más importantes garantías de los administrado en defensa de sus derechos, en cuanto permite hacer valer todos los medios probatorios y argumentaciones ante una entidad imparcial que resolverá conforme a derecho.

En nuestra legislación, el control del ejercicio de la potestad reglamentaria municipal se realiza a través de varios medios, destacando el reclamo de ilegalidad municipal como un mecanismo propio de control jurisdiccional de la actividad municipal.

Nuestro ordenamiento jurídico no contempla un sistema o procedimiento contencioso administrativo de carácter general, no obstante respecto de determinadas materias y en relación con las facultades de algunos órganos de la administración, se establecen procedimientos contenciosos administrativos especiales.

El artículo 136 de la LOCM establece un procedimiento contencioso administrativo especial y breve para reclamar contra las resoluciones $u$ omisiones ilegales del alcalde o de sus funcionarios, cuando éstas afecten el interés general de la comuna o causen agravio. ${ }^{39}$

Nos corresponden determinar en este momento el objeto de este reclamo, el sujeto activo y el procedimiento.

\section{Objeto del reclamo de ilegalidad contra ordenanzas y reglamentos municipa-} les.

Los actos en contra de los cuales procede el ejercicio de este reclamo de ilegalidad comprende al concepto genérico de resoluciones municipales, precisado por el artículo 10 de la LOCM: ordenanzas, reglamentos municipales, decretos alcaldicios o instrucciones. Los dos primeros corresponden justamente a las actuaciones que concretan el ejercicio de la potestad reglamentaria municipal.

Nadie puede discutir que mediante el ejercicio de la potestad reglamentaria municipal se pueden caer en los presupuestos del artículo 136 de la LOCM a través de actos ilegales, es decir, por la dictación de la correspondiente ordenanza o reglamento municipal.

Lo que resulta discutible es la posibilidad que se incurra en una omisión ilegal producto del no ejercicio de la potestad reglamentaria. Lo cierto es que ha resultado habitual encontrar casos de normas de rango legal, que habiendo habilitado a la respectiva autoridad administrativa para que por la vía del reglamento complemente sus preceptos, ésta no ha realizado gestión alguna en tal sentido, dejando sin aplicación tal precepto, conducta o actitud que ha generado los correspondientes perjuicios a los particulares o administrado. Sobre la base de este supuesto, es decir, ante una disposición legal expresa que habilite a la municipalidad para complementar su preceptos como requisito necesario para la aplicación efectiva de la ley, y ante un daño patrimo-

39 Esta acción fue consagrada por primera vez y en términos similares, por el artículo 5 transitorio del $\mathrm{DL} \mathrm{N}^{2} 1.289$ de 1976 (antigua Ley Orgánica de Municipalidades). Al respecto se puede ver el articulo de PIERRY ARRAU, PEDRO: "Reclamo del Agraviado por resolución municipal en el contencioso administrativo municipal", RDUCV, Vol. VI. 1982, p. 403. 
nial efectivo producto de esta omisión, estimamos que procede el ejercicio del reclamo de ilegalidad y la correspondiente indemnización de los perjuicios ocasionados.

¿Que medios existen para reprimir los reglamentos municipales ilegales?. En la primera etapa del procedimiento el alcalde puede dejar sin efecto la correspondiente ordenanza o reglamento, ya sea en todo o parte, a través de la derogación o modificación del mismo ${ }^{40}$. En la etapa judicial, se atribuye la posibilidad de sancionar con la anulación total o parcial de la respectiva ordenanza o reglamento impugnada, pudiendo declarar el derecho a los perjuicios ocasionados por la aplicación de estas normativas.

\section{Sujeto activo para reclamar la ilegalidad de las ordenanzas y reglamentos.}

En general, si la ordenanza o reglamento municipal ilegal afecta el interés general de la comuna, existe una acción popular para reclamar de su ilegalidad, ya que no se limita la acción en cuanto a exigir determinada calidad al recurrente. Como es de toda lógica, toda actuación ilegal de la Municipalidad, considerando el carácter normativo de estos actos, afecta en alguna forma el interés general de la comuna (artículo 136 letra a).

Sin perjuicio de esta acción, toda persona a la cual le ha causado agravio la aplicación de una norma reglamentaria, puede reclamar de la ilegalidad del acto administrativo que da aplicación a la norma y de la ilegalidad de la norma reglamentaria misma para que sea anulada según corresponda, como también en el caso que se omita la dictación de la respectiva ordenanza o reglamento, como por ej. para realizar una actividad comercial, la ley establece que en cada comuna debe dictarse una ordenanza para hacerla operativa, pero la municipalidad no dicta acto alguno sobre la materia, causando un agravio a toda persona que realiza esta actividad económica lícita, más aún si esta omisión le causa perjuicios, los que deberán ser indemnizados ${ }^{41}$ (artículo 137 letra b).

\section{Procedimiento del reclamo de ilegalidad}

El procedimiento para entablar esta acción contra ordenanzas y reglamento municipales, y en general contra cualquier resolución municipal u omisión ilegal, consta de dos etapas: Una administrativa y otra judicial.

La primera, etapa administrativa del reclamo, se realiza ante el alcalde, existiendo un plazo de 30 días para recurrir. Este término se cuenta respecto de las ordenanzas desde su publicación. Tratándose de los reglamentos, que se refieren a materias de orden interno, no existe un mecanismo de publicidad, ya que estos actos no se publican ni se notifican, en este caso la única posibilidad es que el plazo de 30 días se cuente

En nuestro criterio, no procede que el alcalde declare la nulidad del respectivo reglamento u ordenanza, sino que su invalidación, dado que este medio de sanción del reglamento ilegal sólo puede ser aplicado por vía jurisdiccional (articulos 6,7 y 73 de la (PR). Así lo ha entendido el propio legislador que en la letra h) del artículo 136 prevé la anulación sólo respecto del caso en que la Corte de Apelaciones da lugar al reclamo.

41

Estimamos que no puede existir una acción popular respecto de la omisión en la dictación de una ordenanza o reglamento, ya que su ilegalidad está estrechamente vinculada a los perjuicios que ocasiona, cuya reparación se busca mediante este recurso contencioso especial, situación que a priori exige determinada calidad del sujeto activo. 
desde la fecha de su dictación ${ }^{42}$. Respecto a los actos administrativos que aplican ordenanzas y reglamentos, el plazo que tiene el agraviado para reclamar es también de 30 días, pero contado desde la correspondiente notificación administrativa. ${ }^{43}$

Presentado oportunamente el reclamo, el alcalde, dentro del plazo de 15 días, puede aceptarlo, rechazarlo o mantenerse en silencio frente a la solicitud. En caso de negar lugar al reclamo o de silencio administrativo negativo (que se produce cuando el alcalde, dentro del plazo de 15 días contados desde la recepción de la solicitud, no se pronuncia) el solicitante podrá recurrir ante la Corte de Apelaciones respectiva.

Este plazo para recurrir se cuenta desde que se rechaza la solicitud expresamente (contado desde su notificación) o tácitamente (desde que transcurren los 15 días sin que se haya pronunciado el alcalde, hecho que debe certificar el secretario municipal).

Terminada esta etapa administrativa comienza la fase judicial, la cual se inicia con la presentación de un escrito de reclamo por la resolución municipal adoptada ante la Corte de Apelaciones competente.

El tribunal de alzada podrá dictar orden de no innovar, para suspender los efectos del acto impugnado, cuando su ejecución importe un daño irreparable al reclamante. Es de toda lógica que un acto administrativo que aplica un reglamento ilegal pueda ser suspendido en sus efectos, pero ¿Es posible declarar orden de no innovar respecto de un reglamento ilegal? Bien es sabido que uno de los fundamentos de nuestros sistema procesal es el efecto relativo de las sentencias, de manera tal que una resolución judicial no puede afectar, por regla general, a terceros que no han intervenido en el proceso o no han contado con los resguardos mínimos para garantizar su participación en el mismo. La orden de no innovar contra una reglamento significa suspender la aplicación de una norma cuya aplicación puede afectar positiva o negativamente a un grupo amplio de personas cuya determinación puede resultar dificultosa, sin que hayan tenido participación alguna en dicho proceso, de tal forma que debería negarse en principio la procedencia de esta orden no innovativa. Sin embargo, pensamos que ante la concurrencia de los supuestos de procedencia de esta orden (daño irreparable) cualquier persona podrá solicitarla respecto de su caso en concreto, a fin de evitar que, amparándose en la norma reglamentaria, se dicte un acto administrativo que le cause dicho perjuicio. Cuestión distinta es la posterior declaración de nulidad del reglamento que pueda dictarse, cuya declaración es de efectos erga omnes o absolutos, ya que su objetivo es ser un mecanismo de resguardo del principio de superioridad jerárquica de la ley y no de los intereses particulares de los administrados.

Presentado el reclamo, se da traslado por el plazo fatal de 10 días al alcalde. Evacuado el traslado o teniéndose por evacuado en rebeldía, la corte si lo estima necesario, podrá abrir un término de prueba, el que sujetará a las normas de los incidentes. Evacuado el traslado o vencido el término de prueba en su caso, se remitirán los autos al fiscal para su informe y a continuación se ordenará traer los autos en relación, los cuales gozan de preferencia para su vista.

42 PIERRY ARRAU, ob. cit. nota 38, p. 404.

43 Sobre la notificación de los actos administrativa, véase el Dictamen N²2.819 de la CGR, en Gaceta Jurídica N² 158 , agosto de 1993, p. 174 y 175. 
De acuerdo a lo dispuesto en la letra h) del artículo 137 de la LOCM, la Corte de Apelaciones cuenta con diversos medios frente a una actuación municipal ilegal, pero que tratándose de ordenanzas o reglamentos ilegales, estos sólo se limitaran a:

a) la anulación total o parcial de la ordenanza o reglamento impugnado;

b) la declaración del derecho a la indemnización de los perjuicios causados, cuando se ha omitido la dictación del correspondiente reglamento, determinado por la ley, y siempre que se hubiere solicitado.

Pero, si se trata de un acto que aplica el reglamento ilegal, podrá:

a) anular el acto administrativo y el correspondiente reglamento, ya sea en forma total o parcial;

b) declarar el derecho a la indemnización de los perjuicios causados por la aplicación del reglamento.

Esto es sin perjuicio de remitir los antecedentes al juez del crimen que corresponda, cuando tales hechos sean además constitutivos de delito.

En caso de declararse el derecho a la indemnización de los perjuicios, el reclamante deberá concurrir a los tribunales civiles ordinarios y demandar a la municipalidad en juicio sumario para obtener su determinación y pago.

Se ha discutido la procedencia del recurso de apelación en contra de esta resolución ante la Corte Suprema. ${ }^{44}$

Para terminar debemos señalar que la jurisprudencia ha establecido que el reclamo de ilegalidad municipal es compatible con otras vías generales o especiales de impugnación. ${ }^{45}$

CALDERA Delgado, Hugo: "Sistema de Responsabilidad en la Ley Orgánica de Municipalidades" (DL N 1.289/76) RDJ, Tomo LXXVIII, septiembre a diciembre, 1981, p. 110, manifiesta que en contra de la sentencia de la Corte de Apelaciones que resuelve el reclamo proceden los recursos de apelación, casación y queja. En cambio, FERNANDEZ RICHARD, JOSE: "Improcedencia del Recurso de Apelación en Contra de Resolución de la Corte de Apelaciones que se pronuncia sobre un Reclamo de ilegalidad contemplado en el art. 136 de la ley $N^{2} 18.695^{\prime \prime}$. Gaceta Jurídica N²161, noviembre de 1993, p. 19, sostiene la tesis contraria. Es necesario mencionar que de acuerdo al artículo 545 del COT, modificado por la Ley $N^{0} 19.374$, el recurso de queja sólo procederá en cuando la falta o abuso se cometa en sentencia interlocutoria que ponga fin al juicio o haga imposible su continuación o definitiva que no sea susceptible de recurso alguno, ordinario o extraordinario.

Al respecto se puede ver: Gaceta Jurídica N²159, p.170 y Gaceta Jurídica N²170, p. 90. 